\title{
12. CENOZOIC SILICOFLAGELLATES FROM OFFSHORE GUATEMALA, DEEP SEA DRILLING PROJECT SITE 495
}

\author{
David Bukry, United States Geological Survey, Scripps Institution of Oceanography, La Jolla, California
}

\begin{abstract}
Diverse lower Miocene to Pleistocene silicoflagellate assemblages occur at Deep Sea Drilling Project Site 495, but many samples are dominated by one or two taxa. Low-latitude zonation can be applied throughout. Cool-indicating Distephanus speculum s. ampl. is only abundant in the upper Miocene; however, relative paleotemperature values (TS) suggest temperature extremes in the lower Miocene similar to those in the upper Miocene. The lower upper Miocene appears to be thinned or missing, because no Dictyocha brevispina Zone assemblages are identified. The lower Miocene assemblages of the Naviculopsis ponticula Zone are an important silicoflagellate reference because of several new taxa and associations.

New taxa and recombinations described herein include: Corbisema triacantha var. nuda $\mathrm{n}$. var., Dictyocha angulata n. sp., D. delicata n. comb., D. delicata var. bisecta n. var., D. longa n. sp., D. longa var. paxilla n. var., D. ornata ornata n. comb., D. ornata africana n. subsp., D. subaculeata n. comb., Distephanus crux parvus n. comb., D. crux scutulatus $\mathrm{n}$. subsp., D. polyactis var. literatus $\mathrm{n}$. var., D. speculum patulus $\mathrm{n}$. subsp., Naviculopsis contraria $\mathrm{n}$. $\mathrm{sp}$., $N$. lacrima n. sp., N. lata var. obliqua $\mathrm{n}$. var., N. ponticula spinosa n. subsp.
\end{abstract}

\section{INTRODUCTION}

Deep Sea Drilling Project Leg 67 cored a transect of seven sites across the Middle America Trench south of Guatemala to study tectonic accretion and imbrication of strata at a long-active convergent plate margin. Site $495\left(12^{\circ} 29.78^{\prime} \mathrm{N}, 91^{\circ} 02.26^{\prime} \mathrm{W}\right.$, depth, $\left.4140 \mathrm{~m}\right)$ is the distal oceanic reference site on the Cocos Plate, just 22 $\mathrm{km}$ seaward of the trench axis, and 1925 meters above the trench floor. Hole 495 was continuously cored from 19 to 446.5 meters sub-bottom depth, recovering basalt in Cores 46 to 49 , lower and middle Miocene coccolithic ooze-chalk in Cores 20 to 45 , and middle Miocene to Pleistocene diatomaceous muds in Cores 1 to 19. Silicoflagellates are fairly common and widely distributed through both sedimentary lithologies, when acid residue preparations are examined.

Zonation, correlation, and relative paleotemperature index $(T s)$ for the silicoflagellate assemblages are discussed. The systematic paleontology is divided into two sections-previously cited taxonomy and new taxonomy. Several of the new taxa are especially abundant, suggesting that upwelling might have magnified their importance and that the Miocene silicoflagellate succession in the Pacific is still incompletely known.

\section{SILICOFLAGELLATE ZONATION}

The silicoflagellate zonation employed for Site 495 is similar to that developed for nearby DSDP Leg 54 (Bukry, 1980b) and Leg 63 (Bukry, 1981), and is defined in Bukry (in press). Brief characterizations of the zones and subzones cited for Hole 495 (Figs. 1, 2) follow.

\footnotetext{
${ }^{1}$ Aubouin, J., von Huene, R., et al., Init. Repts. DSDP, 67: Washington (U.S. Govt. Printing Office).
}

\section{Dictyocha aculeata Zone}

This upper Pleistocene zone is identified at Site 495 by the high concentration of Dictyocha sp. aff. D. aculeata $(20 \%)$ and $D$. subaculeata $(56 \%)$, with no specimens of Mesocena quadrangula.

\section{Dictyocha delicata Subzone}

This subzone is the upper unit of the Dictyocha stapedia Zone. It is mainly lower Pleistocene. The predominance of Dictyocha delicata $(12 \%)$ over Mesocena quadrangula $(6 \%)$, with Octactis pulchra $(1 \%)$ present, is used to identify the subzone at Site 495 .

\section{Dictyocha ornata Subzone}

This mainly upper Pliocene subzone is identified by the presence of Dictyocha ornata africana or D. ornata ornata and is the lower unit of the Dictyocha stapedia Zone. Although $D$. ornata africana and related forms occur only in Core 9, the high $27 \%$ abundance and conjunction with $D$. perlaevis flexatella $(2 \%)$ are typical for the subzone. Curiously, no D. stapedia stapedia are present.

\section{Dictyocha stapedia Zone}

Some of the upper Pliocene assemblages lack the common subzonal guide taxa Dictyocha delicata or $D$. ornata. These assemblages are assigned to the undivided Dictyocha stapedia Zone on the basis of the abundant D. stapedia stapedia.

\section{Dictyocha fibula Zone}

Dictyocha fibula s. ampl. and D. longa predominate in the Dictyocha populations over asperoid taxa, below the range of $D$. stapedia stapedia. This indicates the Dictyocha fibula Zone of the upper Miocene and lower Pliocene. 


\begin{tabular}{|c|c|c|c|c|c|c|c|c|c|c|c|c|c|c|}
\hline \multirow{3}{*}{$\begin{array}{l}\text { Series or Subseries } \\
\text { Zone } \\
\text { Subzone } \\
\end{array}$} & \multicolumn{2}{|c|}{ Pleistocene } & \multicolumn{7}{|c|}{ Pliocene } & \multicolumn{4}{|c|}{ Upper Miocene } & \multirow{4}{*}{$\begin{array}{l}- \\
\frac{-}{-} \\
162\end{array}$} \\
\hline & \multirow{3}{*}{$\begin{array}{c}\text { D.a. } \\
- \\
20 \\
\end{array}$} & \multicolumn{5}{|c|}{ D. stapedia } & \multicolumn{7}{|c|}{ D. fibula } & \\
\hline & & \multirow{2}{*}{\begin{tabular}{|c|} 
D.d. \\
51 \\
\end{tabular}} & \multicolumn{2}{|c|}{-} & \multirow{2}{*}{\begin{tabular}{|c|} 
D.o. \\
80 \\
\end{tabular}} & \multirow{2}{*}{$\frac{-}{92}$} & \multicolumn{3}{|c|}{-} & D.n. & \multicolumn{3}{|c|}{-} & \\
\hline Sub-bottom Depth (m) & & & 59 & 67 & & & 97 & 110 & 116 & 125 & 135 & 151 & 152 & \\
\hline Taxa & 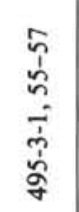 & 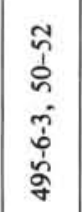 & 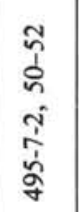 & 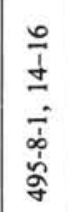 & 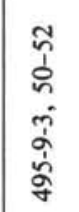 & 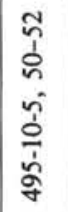 & 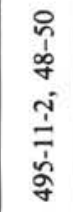 & 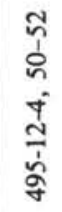 & $\begin{array}{l}\frac{a}{1} \\
\tilde{n} \\
\frac{\dot{m}}{2} \\
\frac{a}{2}\end{array}$ & 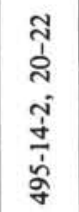 & $\begin{array}{l}\frac{1}{d} \\
\frac{1}{2} \\
\frac{a}{\mathfrak{n}}\end{array}$ & $\begin{array}{l}\frac{1}{d} \\
\frac{1}{\dot{b}} \\
\frac{a}{2}\end{array}$ & $\begin{array}{l}\frac{1}{0} \\
\frac{\pi}{\frac{1}{2}}\end{array}$ & 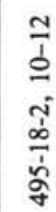 \\
\hline $\begin{array}{l}\text { Dictyocha sp. aff. D. aculeata } \\
\text { D. angulata } \\
\text { D. aspera } \text { [large] } \\
\text { D. aspera } \text { s. ampl. [small] } \\
\text { D. brevispina brevispina }\end{array}$ & 20 & & & 1 & & 1 & $\begin{array}{l}7 \\
2 \\
1\end{array}$ & & 2 & 1 & 19 & 16 & $\begin{array}{l}2 \\
3\end{array}$ & \\
\hline $\begin{array}{l}\text { D. calida ampliata } \\
\text { D. calida calida } \\
\text { D. delicata var. bisecta } \\
D \text {. delicata } \\
D . \text { sp. aff. } D \text {. delicata }\end{array}$ & 1 & $\begin{array}{r}4 \\
12\end{array}$ & 8 & & $\begin{array}{r}<1 \\
2 \\
1\end{array}$ & $\begin{array}{r}21 \\
3\end{array}$ & 2 & & & & & & & \\
\hline $\begin{array}{l}\text { D. fibula fibula s. ampl. } \\
\text { D. longa var. } \\
\text { D. longa var. paxilla } \\
\text { D. sp. aff. D. neonautica } \\
\text { D. neonautica var. cocosensis }\end{array}$ & & 6 & & & 34 & 1 & $\begin{array}{r}4 \\
39\end{array}$ & & $\begin{array}{r}7 \\
1 \\
68\end{array}$ & $\begin{array}{r}18 \\
29 \\
1 \\
6\end{array}$ & $\begin{array}{l}16 \\
52\end{array}$ & 21 & 51 & \\
\hline $\begin{array}{l}\text { D. ornata africana } \\
D . \text { sp. aff. } D \text {. ornata africana } \\
\text { D. perlaevis flexatella } \\
\text { D. perlaevis perlaevis } \\
D \text {. pulchella } \\
\end{array}$ & 2 & 10 & $\begin{array}{l}1 \\
5 \\
1 \mathrm{D}\end{array}$ & $\begin{array}{l}3 \\
1\end{array}$ & $\begin{array}{r}17 \\
10 \\
2 \\
5\end{array}$ & 30 & 32 & & 6 & & 1 & $\begin{array}{l}1 \\
1\end{array}$ & 4 & \\
\hline $\begin{array}{l}\text { D. stapedia aspinosa } \\
\text { D. stapedia stapedia } \\
\text { D. subaculeata } \\
\text { D. spp. [asperoid] } \\
\text { D. spp. [fibuloid] }\end{array}$ & $\begin{array}{l}12 \\
56\end{array}$ & 58 & 65 & $\begin{array}{r}21 \\
63 \\
1\end{array}$ & 21 & $\begin{array}{l}12 \\
21\end{array}$ & & & & 1D & & 1 & & \\
\hline $\begin{array}{l}\text { D. spp. } \\
\text { Distephanus boliviensis } \\
\text { D. mesophthalmus } \\
\text { D. polyactis var. literatus } \\
\text { D. quinquangellus }\end{array}$ & 9 & $\begin{array}{l}2 \\
2\end{array}$ & 11 & $\begin{array}{l}1 \\
1\end{array}$ & 1 & 2 & $\begin{array}{l}4 \\
2\end{array}$ & & $\begin{array}{l}2 \\
1\end{array}$ & $\begin{array}{l}1 \\
3 \\
1\end{array}$ & 5 & & 2 & \\
\hline $\begin{array}{l}\text { D. speculum minutus } \\
\text { D. speculum speculum } \mathrm{s} \text {. ampl. } \\
\text { D. spp. [cruxoid] } \\
\text { Mesocena circulus } \\
\text { M. quadrangula }\end{array}$ & & $\begin{array}{l}2 \\
6 \\
\end{array}$ & 1 & $\begin{array}{l}1 \\
1 \\
2 \\
1\end{array}$ & $\begin{array}{l}1 \\
8\end{array}$ & 6 & 7 & & $\begin{array}{r}15 \\
1\end{array}$ & $\begin{array}{r}1 \\
37 \\
1\end{array}$ & $\begin{array}{l}5 \\
1\end{array}$ & 60 & $\begin{array}{r}40 \\
1\end{array}$ & \\
\hline Octactis pulchra & & 1 & & & & & & & & & & & & \\
\hline Total Specimens & 100 & 200 & 100 & 200 & 300 & 100 & 100 & 0 & 200 & 200 & 200 & 100 & 200 & 0 \\
\hline Relative Paleotemperature Value & 100 & 92 & 87 & 91 & 92 & 92 & 91 & - & 86 & 62 & 93 & 40 & 62 & - \\
\hline
\end{tabular}

Figure 1. Upper Miocene to Pleistocene silicoflagellates recorded as percentages from Cores 3 to 18 of Site 495 . (See text for zone and subzone abbreviations. $\mathrm{D}=$ displaced. Dashes indicate no subzone name or interpretation was possible for the sample interval.)

\section{Dictyocha neonautica Subzone}

The conjunction of Dictyocha neonautica with $D$. longa and Distephanus mesophthalmus in Core 14 is characteristic of the Dictyocha neonautica Subzone in the Eastern Pacific. DSDP Site 157 in the Panama Basin has the conjunction of $D$. neonautica and D. mesophthalmus in the upper Miocene, recorded as Dictyocha navicula and Distephanus parvus (Bukry and Foster, 1973). Similarly, DSDP Site 471, off Baja California, has these three key taxa in conjunction, with $D$. longa recorded as D. fibula (elongate) (Bukry, 1981).

\section{Corbisema triacantha Zone}

This lower and middle Miocene zone is identified by the presence of Corbisema triacantha above the extinction of Naviculopsis. No specimens of subzonal guide species Distephanus stauracanthus are present in samples from Site 495. 


\begin{tabular}{|c|c|c|c|c|c|c|c|c|c|c|c|}
\hline \multirow{3}{*}{$\begin{array}{l}\text { Subseries } \\
\text { Zone } \\
\text { Sub-bottom Depth (m) }\end{array}$} & \multicolumn{2}{|c|}{ M. Miocene } & \multicolumn{9}{|c|}{ Lower Miocene } \\
\hline & \multicolumn{4}{|c|}{ C. triacantha } & \multicolumn{6}{|c|}{ N. ponticula } & \multirow{2}{*}{$\begin{array}{c}\begin{array}{c}\text { N. lata } \\
\text { or }\end{array} \\
\text { N. quadrata } \\
337\end{array}$} \\
\hline & 182 & 188 & 267 & 273 & 286 & 289 & 292 & 297 & 301 & 309 & \\
\hline (interval in cm) & 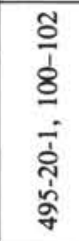 & 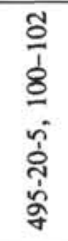 & 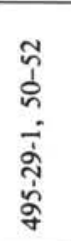 & 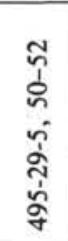 & 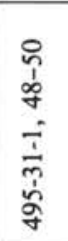 & 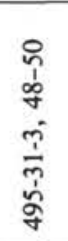 & 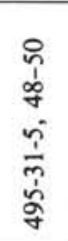 & 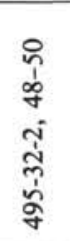 & 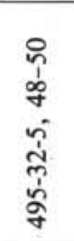 & 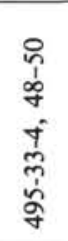 & 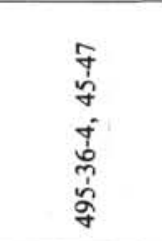 \\
\hline $\begin{array}{l}\text { Corbisema triacantha var. nuda } \\
\text { C. triacantha } \\
\text { Dictyocha sp. aff. D. aspera } \\
\text { D. brevispina ausonia } \\
D \text {. brevispina brevispina }\end{array}$ & $\begin{array}{r}18 \\
7 \\
16\end{array}$ & & $\begin{array}{r}6 \\
2 \\
49\end{array}$ & $\begin{array}{l}9 \\
1 \\
6\end{array}$ & 5 & & $<1$ & 1 & $<1$ & & 2 \\
\hline $\begin{array}{l}\text { D. fibula fibula } \\
\text { D. pulchella } \\
D \text {. pulchella [cruxoid] } \\
D . \text { sp. aff. D. pulchella } \\
D . \text { spp. }\end{array}$ & $\begin{array}{l}21 \\
30\end{array}$ & $\begin{array}{l}x \\
x\end{array}$ & & $\begin{array}{l}2 \\
1\end{array}$ & & & & $<1$ & $<1$ & & \\
\hline $\begin{array}{l}\text { Distephanus crux s. ampl. } \\
\text { D. crux s. ampl. [dictyochoid] } \\
\text { D. crux parvus } \\
\text { D. crux scutulatus } \\
\text { D. crux scutulatus [fibuloid] }\end{array}$ & $\begin{array}{l}4 \\
5\end{array}$ & $\mathrm{x}$ & $\begin{array}{l}26 \\
14 \\
\end{array}$ & $\begin{array}{r}82 \\
1 \\
\end{array}$ & 36 & $\begin{array}{r}14 \\
2 \\
22\end{array}$ & $\begin{array}{l}3 \\
4 \\
2\end{array}$ & 5 & $\begin{array}{r}<1 \\
55\end{array}$ & 81 & 1 \\
\hline $\begin{array}{l}D . \text { sp. aff. D. schauinslandii } \\
D . \text { sp. aff. D. staurodon } \\
D . \text { speculum haliomma } \\
D . \text { speculum hemisphaericus } \\
D . \text { speculum patulus }\end{array}$ & & & 1 & & 27 & 8 & 6 & 6 & $\begin{array}{l}1 \\
2\end{array}$ & $\begin{array}{l}2 \\
2\end{array}$ & 29 \\
\hline $\begin{array}{l}\text { D. speculum polyommata } \\
D \text {. speculum speculum } \mathrm{s} \text {. ampl. } \\
\text { Mesocena apiculata curvata } \\
\text { M. diodon nodosa } \mathrm{s} \text {. ampl. } \\
\text { M. sp. cf. M. quadrangula }\end{array}$ & $\begin{array}{l}1 \\
1 \\
\end{array}$ & $\mathrm{X}$ & 2 & 1 & 7 & 2 & 1 & & 34 & 2 & \\
\hline $\begin{array}{l}\text { Naviculopsis contraria } \\
N . \text { sp. aff. } N . \text { contraria [barred] } \\
N . \text { sp. aff. } N \text {. contraria [spired] } \\
N . \text { eobiapiculata } \\
N \text {. lacrima }\end{array}$ & & & & & & & $\begin{array}{r}72 \\
3 \\
3\end{array}$ & 62 & & & 1 \\
\hline $\begin{array}{l}N . \text { sp. aff. } N . \text { lacrima } \\
N . \text { lata } \\
N . \text { sp. aff. } N . \text { lata } \\
N . \text { navicula } \\
N . \text { sp. aff. } N \text {. navicula }\end{array}$ & & & & & & & $\begin{array}{r}5 \\
<1\end{array}$ & 4 & 2 & $\begin{array}{l}2 \\
1 \\
\end{array}$ & 66 \\
\hline $\begin{array}{l}N . \text { obtusarca } \\
N . \text { sp. aff. } N \text {. obtusarca } \\
N . \text { ponticula ponticula } \\
N \text {. ponticula spinosa } \\
N . \text { quadrata } \\
\end{array}$ & & & & & $\begin{array}{r}9 \\
18\end{array}$ & 52 & $<1$ & $\begin{array}{r}11 \\
6 \\
*\end{array}$ & 4 & 6 & 1 \\
\hline N. spp. & & & & & & & & & & & 1 \\
\hline Total Specimens & 200 & 8 & 100 & 200 & 100 & 50 & 300 & 300 & 300 & 300 & 300 \\
\hline Relative Paleotemperature Value & 97 & $\mathrm{x}$ & 77 & 61 & 26 & 19 & 5 & 5 & 29 & 43 & 3 \\
\hline
\end{tabular}

Figure 2. Lower and middle Miocene silicoflagellates recorded as percentages from Cores 20 to 36 of Site 495 . (X) present; count too small for meaningful percentage calculation. $\mathrm{D}=$ displaced. ${ }^{*}=$ recorded after counts.)

\section{Naviculopsis ponticula Zone}

This lower Miocene zone is identified by the total range of Naviculopsis ponticula, typically above the last $N$. quadrata. Although previously correlated with the coccolith Helicosphaera ampliaperata Zone, the Naviculopsis ponticula Zone is associated with the older coc- colith Sphenolithus belemnos Zone at Site 495 in Core 31 . (The 3-meter recovery from the 10 -meter cored interval of Core 30 was not examined.)

Naviculopsis lata Zone or Naviculopsis quadrata Zone

The lowest silicoflagellate assemblage studied at Site 495 contains abundant Naviculopsis lata $(66 \%)$, which 
characterizes the lower Miocene Naviculopsis lata Zone or overlying Naviculopsis quadrata Zone. The presence of sparse $N$. quadrata $(1 \%)$ indicates probable correlation with the $N$. quadrata Zone, but the low $1 \%$ abundance level could result from contamination.

\section{CORRELATION OF SITE 495}

Upper Pleistocene Dictyocha aculeata Zone assemblages are cosmopolitan. The assemblage of Sample $495-3-1,55-57 \mathrm{~cm}(20 \mathrm{~m}=$ sub-bottom depth) is most similar to that of Sample 425-3-5, 74-76 cm (31 m) (Bukry, 1980b) on the basis of the identical long-barred form of Dictyocha sp. aff. D. aculeata. Diversity, however, is only half as great at Site 495 .

The occurrence of a Dictyocha delicata Subzone assemblage in lower Pleistocene Sample 495-6-3, 50-52 cm is the northernmost record of this subzone. Previous DSDP drilling showed it present to the south (Leg 54) but missing to the north (Leg 63). This subzone is known as far south as Site 157 (Leg 16), located at a latitude of $1^{\circ} 45.70^{\prime} \mathrm{S}$, and Site 321 (Leg 34), at $12^{\circ}$ $01.29^{\prime} \mathrm{S}$ (Bukry, 1976c). The species arrays and relative abundances are very similar among the early Pleistocene sediments at Sites 157, 321, and 495.

The Dictyocha ornata Subzone of the Atlantic Ocean upper Pliocene is definitely identified in the Pacific for the first time. The guide species Dictyocha ornata africana and $D$. sp. aff. D. ornata africana constitute $27 \%$ of the assemblage of Sample 495-9-3, 50-52 cm. Shipboard coccolith studies assigned this core to the upper Pliocene Discoaster brouweri Zone, which supports crosscorrelations from DSDP Legs 37, 40, 47, and 49 in the North and South Atlantic. Specifically, the acme of D. ornata africana is associated with the coccolith Discoaster tamalis Subzone or Discoaster surculus Subzone. The association of $2 \% \mathrm{D}$. perlaevis flexatella, which ranges from upper Pliocene to lowermost Pleistocene, also assists in relating the subzone to Atlantic areas. Because of the limited occurrence at Site 495 of the subzonal guide species and the small number of samples examined, the $D$. ornata Subzone is only identified from one sample, instead of the whole $D$. stapedia Zone interval below $D$. delicata delicata s. str. (Bukry, in press).

The identification and correlation of the Dictyocha fibula Zone is aided in the eastern Pacific by the occurrence of Dictyocha neonautica in the upper upper Miocene and $D$. long $a$ and $D$. long $a$ var. paxilla in the upper upper Miocene and Pliocene. D. longa, which appears to be an elongate form, transitional between $D$. fibula and $D$. perlaevis, is the dominant fibuloid silicoflagellate near the Miocene/Pliocene boundary and within the $D$. neonautica Subzone. D. longa s. ampl. has been recorded as far south as Site $425\left(1^{\circ} 23.68^{\prime} \mathrm{N}\right)$ near the Islas Galapagos in lowermost Quaternary or uppermost Pliocene strata that contain D. ornata africana (Bukry, $1980 \mathrm{~b})$. Whereas this occurrence duplicates its upper Pliocene acme in Sample 495-9-3, 50-52 cm, the southern range of the earliest appearance is uncertain because Site 425 lacks any Miocene strata. The northern range of $D$. longa s. ampl. includes Site 471 with $D$. neo- nautica in the upper Miocene. A few specimens also occur in the upper Miocene D. fibula Zone of Site 470 east of Isla Guadalupe. Site 495 is within the eastern Pacific geographic range of $D$. longa s. ampl., and the age limits are similar to those previously determined at Sites 425 and 471.

The Dictyocha neonautica Subzone has been identified at several DSDP sites in the Pacific, including Sites $77,158,303,310$, and 471 . It is typically associated with the upper Miocene coccolith Amaurolithus primus Subzone.

The lack of any Dictyocha brevispina Zone in Cores 18 and 20 suggests an hiatus or dissolution thinning of the upper middle or lower upper Miocene.

The Corbisema triacantha Zone assemblages of Site 495 contain moderate numbers of Corbisema triacantha triacantha in the upper (Core 20) and lower (Core 29) portions of the zone that were examined. An abundant $(18 \%)$ occurrence of the new subspecies $C$. triacantha var. nuda provides a potential regional correlation tool, because this same form was recorded at Site 469 off southern California (Bukry, 1981). Both occurrences are assigned to the middle Miocene portion of the $C$. triacantha Zone. Detailed correlation of the Site 495 assemblages is limited by their low diversity. There are no Cannopilus and only sparse, sporadic Mesocena and members of the Distephanus speculum complex. The subzonal guide species Distephanus stauracanthus was not recorded from the upper samples, probably because the older part of the $C$. triacantha Zone was sampled. The general absence of Mesocena apiculata curvata in the upper part of the zone and of Mesocena diodon nodosa in the lower part is supported by the sparse Mesocena population here (Bukry, 1978b, 1980a) (Fig. 2).

The Naviculopsis ponticula Zone of Cores 31 to 33 is characterized by abundant Naviculopsis and persistent Distephanus crux scutulatus and D. speculum patulus. Aside from a local acme of Mesocena sp. cf. M. quadrangula $(34 \%)$ in Core 32 , other species are sparse. The top of the zone in Core 31 is associated with the Sphenolithus belemnos Zone of coccoliths, which is slightly older than the Helicosphaera ampliaperta Zone associations at Atlantic reference Sites 369 (Hole 369A), 407, and $415 . D$. crux s. ampl. is prominent in all of the assemblages, however, Site 495 is distinguished by the paucity of Corbisema, a moderate number of Distephanus speculum subspecies, and the great abundances of Naviculopsis. This suggests cooler conditions than for the other reference sites. A greater abundance of Naviculopsis ponticula at Site 495 and the presence of two new elongate species, $N$. contraria and $N$. lacrima, indicates special conditions at Site 495 , possibly related to intense upwelling.

The deepest assemblage studied is assigned to the lower Miocene Naviculopsis lata Zone or Naviculopsis quadrata Zone. As in most Site 495 assemblages, diversity is lower than other areas and one or two species dominate, probably the result of strong upwelling. The nearly complete dominance of Naviculopsis lata $(66 \%)$ and Distephanus speculum patulus $(29 \%)$ is a unique combination not observed at other DSDP reference sites 
for these zones, such as Sites 186, 266, 338, 369, 370, and 407. The sparseness of Distephanus crux s. ampl. is unusual. Even though $N$. lata is the dominant species, the sparse presence of $N$. quadrata suggests the Naviculopsis quadrata Zone here or just above. Associated coccoliths are correlated to the lower Miocene Triquetrorhabdulus carinatus Zone (Bukry, 1975a) because of the presence of Helicosphaera carteri, Triquetrorhabdulus carinatus, and $T$. milowii and the absence of Discoaster druggii and Sphenolithus belemnos.

\section{RELATIVE PALEOTEMPERATURE VALUES $(T s)$}

Relative paleotemperature values for silicoflagellate assemblages in DSDP sites from Cape Mendocino, California to Cabo Corrientes, Mexico were calculated for DSDP Leg 63 (Bukry, 1981). These values, based on the relation $T s=X w+0.5 X t$, were calculated using the percentages of the genera Corbisema and Dictyocha for warm taxa $(X w)$ and quadrate Distephanus for temperate taxa $(X t)$. The resulting $T s$ values increased towards the equator as expected, and fluctuations were in agreement with paleotemperature trends indicated by associated foraminifers and diatoms. Site 495 lies $11^{\circ}$ farther south than Site 472 at the southern end of the transect studied for Leg 63. Ts values for the late Miocene are similar betwen the two sites, with high values of 93 and 94 and low values of 40 and 50 .

The coolest $T s$ value indicated for the late Miocene in the Site 471 and 472 area is 48 , in the Dictyocha neonautica Subzone of Sample 471-10-1, 20-22 cm. The correlative D. neonautica Subzone in Sample 495-14-2, 20-22 $\mathrm{cm}$ has a $T s$ of 62 , which is distinctly cooler than samples above and below. Further, species compositions and abundance percentages of the two locales are similar, which implies that the cooling at the time of the $D$. neonautica acme was a regional effect, and not just the result of a local upwelling regime. See Keller (1980) for a discussion of latest Miocene Pacific cooling.

The middle Miocene Corbisema triacantha Zone is represented by a sample having a high $T s$ of 97 , which exceeds any at Site 472 by 18 points. This high value does, however, continue the equatorward trend of increasing values. In addition, this $T S$ is the high value of a trend at Site 495 that shows lower values in the lower Miocene portion of the $C$. triacantha Zone.

On the basis of previously determined levels (Douglas and Savin, 1973), the Ts values appear to be too low in the lower Miocene Naviculopsis zones of Site 495. Aside from one value of 43 , the others range from 3 to 29. These low values result from the dominance of Naviculopsis, a genus not calculated in the $T s$ values for the middle Miocene to Holocene, because it became extinct near the end of the early Miocene. Similar low values occur only in the upper Miocene and Pliocene at higherlatitude sites off California (Bukry, 1981a). Whether TS values for the early Miocene are comparable to more recent periods depends on the upwelling or temperature response of the extinct genus Naviculopsis. The distribution and abundance of Naviculopsis and Distephanus speculum s. ampl. in DSDP lower Miocene cores show that Naviculopsis was a cosmopolitan genus that favored cool conditions. For example, examination of the lower Miocene assemblages from the Southern Ocean, Greenland-Norwegian Sea, and subtropical Atlantic (DSDP Sites 266, 278, 338, 369, 391, and 407) shows the highest percentages of both cool-indicating $D$. speculum and Naviculopsis occur at high-latitude sites. Averages are lower at low-latitude Sites 369 and 391.

If Naviculopsis were considered a warm-water taxa (Ciesielski, 1975) because of its bar (instead of ring) apical structure, like Dictyocha, then the modified Ts values at DSDP Site 495 should increase to high levels between 70 and 90 . The exceptions are Sections 495-31-1 $(T s=54), 495-32-2(T s=35)$, and 495-33-4 $(T s=53)$, which remain low, still suggesting that the coolest temperatures of the early Miocene assemblages would have been in the same range as the coolest temperatures of the assemblages of the late Miocene (Fig. 1).

\section{SYSTEMATIC PALEONTOLOGY OF PREVIOUSLY CITED TAXA}

\section{Genus CORBISEMA Hanna, 1928}

Corbisema triacantha (Ehrenberg) Hanna

Dictyocha triacantha Ehrenberg, 1844a, p. 80.

Corbisema triacantha (Ehrenberg) Hanna, 1931, p. 198, pl. D, fig. 1 [s. ampl., Eocene specimen].

\section{Genus DICTYOCHA Ehrenberg, 1837}

Dictyocha aculeata (Lemmermann) Dumitrică

(Plate 1, Fig. 7)

Dictyocha fibula var. aculeata Lemmermann, 1901, p. 261, pl. 11, figs. 1, 2.

Dictyocha aculeata (Lemmermann) Dumitrică, 1973a, p. 907, pl. 9, figs. 5-10.

Dictyocha aculeata aculeata (Lemmermann), Bukry, 1980b, p. 549.

\section{Dictyocha aegea Stradner and Bachmann}

Dictyocha aegea Stradner and Bachmann, 1978, p. 805, pl. 1, figs. 1216; fig. 1.

Dictyocha venzoi Morlotti and Rio, 1978 [1980], p. 102, pl. 2, figs. 5, 6; pl. 3, fig. 1 .

Remarks. The Pacific and Aegean Pliocene elongate specimens of Dictyocha having squared-off portals are classified as D. aegea. They are distinguished from the similar species $D$. angulata by their elongation and recurved side-portals at the minor-axis spines. Length-width ratio for typical $D$. aegea is 1.7 , for the $D$. venzoi type suite it is 1.6 , and for new $D$. angulata it is 1.2 .

\section{Dictyocha aspera (Lemmermann) Bukry and Foster}

Dictyocha fibula var. aspera Lemmermann, 1901, p. 260, pl. 10, figs. $27,28$.

Dictyocha aspera (Lemmermann) Bukry and Foster, 1973 (in part), p. 826 , pl. 2, figs. 4,6 .

Dictyocha aspera aspera (Lemmermann), Bukry, 1975a, p. 700, pl. 4, figs. 7,8 .

\section{Dictyocha brevispina ausonia (Deflandre) Bukry}

Dictyocha ausonia Deflandre, 1950 (in part), p. 195, figs. 194, 195, 196?, 199-202.

Dictyocha brevispina ausonia (Deflandre) Bukry, 1978a, p. 697, pl. 1, figs. 17-19.

\section{Dictyocha brevispina brevispina (Lemmermann) Bukry}

Dictyocha fibula var. brevispina Lemmermann, 1901, p. 260; Ehrenberg, 1854 (in part), pl. 21, fig. 42b; pl. 22, fig. 42a, b. Dictyocha brevispina (Lemmermann) Bukry, 1976c, p. 723. 


\section{Dictyocha calida ampliata Bukry}

Dictyocha calida ampliata Bukry, 1979b, p. 982, pl. 2, figs. 1, 2, 9.

Dictyocha calida calida Poelchau

(Plate 2, Fig. 2)

Dictyocha calida Poelchau, 1976, p. 169, pl. 1, figs. c, d: pl. 3, figs. $\mathrm{a}-\mathrm{f}$.

Dictyocha calida calida Poelchau, Bukry, 1979b, p. 982, pl. 2, figs. 3,4 .

\section{Dictyocha fibula fibula Ehrenberg}

Dictyocha fibula Ehrenberg, 1839, fide Loeblich III et al., 1968, p. 90, pl. 9, figs. 7-12.

Dictyocha fibula fibula Ehrenberg, Bukry, 1978a, p. 697, pl. 2, figs. 1,2 .

Dictyocha fibula Ehrenberg, Bukry, 1980a, p. 514, pl. 2, figs. 1, 2.

Dictyocha neonautica Bukry

Dictyocha neonautica Bukry, in press, p. 442

Dictyocha neonautica neonautica Bukry, Bukry, 1981, pl. 3, fig. 4.

Dictyocha neonautica var. cocosensis Bukry

(Plate 3, Figs. 9-10)

Dictyocha neonautica var. cocosensis Bukry, in press, p. 442

Dictyocha neonautica var. cocosensis Bukry, Bukry, 1981, pl. 3, figs. $1-3$.

\section{Dictyocha perlaevis flexatella Bukry}

(Plate 4, Fig. 4)

Dictyocha perlaevis flexatella Bukry, 1979b, p. 984, pl. 3, figs. 1-3.

Dictyocha perlaevis perlaevis Frenguelli

Dictyocha perlaevis Frenguelli, 1951, p. 279, fig. 4b, c.

Dictyocha perlaevis perlaevis Frenguelli, Bukry, 1976c, p. 724, pl. 2, figs. 4,5 .

\section{Dictyocha pulchella Bukry}

(Plate 4, Fig, 6)

Dictyocha pulchella Bukry, 1975a, p. 687, pl. 4, figs. 1-3.

Dictyocha stapedia aspinosa Bukry

Dictyocha stapedia aspinosa Bukry, 1976c, p. 724, pl. 2, figs. 6-9.

Dictyocha stapedia stapedia Haeckel

Dictyocha stapedia Haeckel, 1887, p. 1561, pl. 101, figs. 10-12.

Dictyocha stapedia stapedia Haeckel, Bukry, 1976c, p. 724, pl. 3, figs.

\section{Genus DISTEPHANUS Stöhr, 1880}

Distephanus boliviensis (Frenguelli) Bukry and Foster

Dictyocha boliviensis Frenguelli, 1940, p. 44, fig. 4.

Distephanus boliviensis (Frenguelli) Bukry and Foster, 1973, p. 827, pl. 4 , figs. $1-3$.

Distephanus boliviensis boliviensis (Frenguelli), Bukry, 1975a, p. 688

\section{Distephanus crux (Ehrenberg) Haeckel}

Dictyocha crux Ehrenberg, 1840, p. 207; Ehrenberg, 1854, pl. 18, fig. 56; pl. 20 (1), fig. 46 ; pl. 33 (15), fig. 9; pl. 33 (16), fig. 9; pl. 33 (17), fig. 5 .

Distephanus crux (Ehrenberg) Haeckel, 1887, p. 1563.

not Distephanus crux (Ehrenberg), Locker, 1974 (in part), p. 637, pl. 3 , fig. 8 .

Remarks. Dictyocha crux illustrated by Ehrenberg (1854) has no apical pikes; Dictyocha mesophthalma does. Therefore, Locker's (1974) selection of a lectotype with apical pikes for D. crux is erroneous. The type suite of Distephanus crux is shown in the published illustrations of 1854 , as validated by Loeblich et al. (1968). Locker
(1974) illustrated a specimen as Distephanus crux that has four apical pikes, as a lectotype from preparation Caltanisetta 18 br of Ehrenberg. Ehrenberg described D. crux in 1840 from Caltanisetta without mention of pikes; later in 1844 he described $D$. mesophthalma from Caltanisetta as having apical pikes. Ehrenberg's illustrations from Mikrogeologie in 1854 show D. crux has no apical pikes, whereas $D$. mesophthalma does. Therefore, Ehrenberg's illustrations of $D$. crux from 1854 are accepted as the type suite; Locker's later illustration could be ascribed to $D$. mesophthalmus. The two most similar specimens from Ehrenberg's illustrations (pl. 8, figs. 29 and 32, of Loeblich et al., 1968) are the best present consensus as to which morphology should be recognized for the name $D$. crux. These majority specimens show little elongation and nearly equant major and minor spines, with square apical and basal rings.

\section{Distephanus mesophthalmus (Ehrenberg) Dumitrică} (Plate 5, Fig. 3)

Dictyocha mesophthalma Ehrenberg, 1844a, p. 64, 80; Ehrenberg. 1854 , pl. 22, fig. 43.

Dictyocha crux Ehrenberg forma parva Bachmann in Ichikawa et al., 1967 (in part), p. 156, pl. 4, figs. 16?, 25-27.

Distephanus parvus (Bachmann) Bukry and Foster, 1973, p. 828, pl. 5 , figs. 2,3 .

Distephanus mesophthalmus (Ehrenberg) Dumitrică, 1973b, p. 850, pl. 6, figs. 9, 10, 12, 13 .

Distephanus crux (Ehrenberg), Locker, 1974 (in part), p. 637, pl. 3, fig. 8 .

\section{Distephanus quinquangellus Bukry and Foster} (Plate 5, Figs. 5-6)

Distephanus quinquangellus Bukry and Foster, 1973, p. 828, pl. 5, fig. 4.

Distephanus schauinslandii Lemmermann

Distephanus schauinslandii Lemmermann, 1901, p. 262, pl. 11, figs. $4,5$.

Distephanus schauinslandii Lemmermann, Bukry, 1978b, p. 817, pl. 4 , figs. 9,10 .

\section{Distephanus staurodon (Ehrenberg) Bukry}

Dictyocha staurodon Ehrenberg, 1844a, p. 80; Ehrenberg, 1854, pl. 18, fig. 58.

Dictyocha staurodon Ehrenberg, Locker, 1974, p. 637, 642; pl. 3, fig. 10.

Distephanus staurodon (Ehrenberg) Bukry, 1978a, p. 697.

\section{Distephanus stradneri (Jerković) Bukry}

Dictyocha schauinslandii Lemmermann, Stradner, 1961 (in part), p. 92 , fig. 60 .

Dictyocha schauinslandii stradneri Jerković, 1965, p. 3, pl. 2, fig. 2; Stradner, 1961, fig. 60.

Distephanus stradneri (Jerković) Bukry, 1978a, p. 698.

Distephanus pusillus Ling, 1977, p. 211, pl. 2, figs. 18-21.

Distephanus stradneri (Jerković), Bukry, 1978b, p. 818, pl. 5, fig. 1. Remarks. Large quadrate Distephanus with fairly straight sides and a small apical opening, like Stradner's original figure, are classified as Distephanus stradneri. Variation in spine length is considered to be intraspecific within this species.

\section{Distephanus speculum haliomma (Ehrenberg) Bukry}

Dictyocha haliomma Ehrenberg, 1844a, p. 64, 80; Ehrenberg, 1854, pl. 21, fig. 46.

Distephanus speculum haliomma (Ehrenberg) Bukry, 1978a, p. 697, pl. 2, fig. 10 .

\section{Distephanus speculum hemisphaericus (Ehrenberg) Bukry}

Dictyocha hemisphaerica Ehrenberg, 1844b, p. 258, 266; Lemmermann, 1901, pl. 11, fig. 21 (fide Loeblich et al., 1968).

Distephanus speculum hemisphaericus (Ehrenberg) Bukry, 1975b, p. 855 , pl. 4 , fig. 8 . 


\section{Distephanus speculum minutus (Bachmann) emend. Bukry}

Dictyocha speculum $\mathrm{f}$. minuta Bachmann in Ichikawa et al., 1967, p. 161 , pl. 7 , figs. $12-15$.

Distephanus minutus (Bachmann) Bukry and Foster, 1973, p. 828, pl. 4 , figs. $10,11$.

Distephanus speculum minutus (Bachmann) emend. Bukry, 1981 [recombined at subspecies level].

\section{Distephanus speculum polyommata (Schulz) Bukry}

Cannopilus hemisphaericus f. polyommata Schulz, 1928, p. 268, 278; fig. $64 \mathrm{a}, \mathrm{b}$.

Distephanus speculum polyommata (Schulz) Bukry, 1978b, p. 818.

\section{Distephanus speculum speculum (Ehrenberg) Haeckel}

Dictyocha speculum Ehrenberg, 1839, p. 150; Ehrenberg, 1854, pl. 18, fig. 57 ; pl. 19 , fig. 41 ; pl. 21 , fig. 44 ; pl. 22 , fig. 47.

Distephanus speculum (Ehrenberg) Haeckel, 1887, p. 1565.

Genus MESOCENA Ehrenberg, 1843

Mesocena apiculata curvata Bukry

(Plate 6, Figs. 1-2)

Mesocena apiculata curvata Bukry, 1976b, p. 849, pl. 2, figs. 15, 16.

Mesocena circulus (Ehrenberg) Ehrenberg

Dictyocha (Mesocena) circulus Ehrenberg 1840, p. 208; Ehrenberg, 1854 , pl. 19, fig. 44 as Mesocena.

Mesocena circulus (Ehrenberg) Ehrenberg, 1844a, p. 65.

\section{Mesocena diodon nodosa Bukry}

Mesocena diodon nodosa Bukry, $1978 \mathrm{~b}$ (in part), p. 818 , pl. 5, figs. 14, 15; pl. 6, figs. 1-3, [not figs. 4, 5, which are now part of Mesocena diodon borderlandensis Bukry, 1981].

\section{Mesocena quadrangula Ehrenberg ex Haeckel}

Mesocena quadrangula Ehrenberg ex Haeckel, 1887, p. 1556; Lemmermann, 1901, pl. 10, figs. 5-7; fide Loeblich et al., 1968, p. 57.

Mesocena quadrangula Ehrenberg ex Haeckel, Bukry, 1978b, p. 819, pl. 7 , figs. 1-5

\section{Genus NAVICULOPSIS Frenguelli, 1940}

Naviculopsis eobiapiculata Bukry

Naviculopsis eobiapiculata Bukry, 1978c, p. 787, pl. 4, figs. 9-16.

\section{Naviculopsis lata (Deflandre) Frenguelli}

(Plate 7, Figs. 11-14)

Dictyocha biapiculata var. lata Deflandre, 1932, p. 500, figs. 30,31 Naviculopsis lata (Deflandre) Frenguelli, 1940, p. 61, fig. 11h.

Naviculopsis lata (Deflandre), Bukry, 1978b, p. 820, pl. 9, figs. 1, 2; pl. 19; fig. 16.

Remarks. The Naviculopsis lata population is bimodal on the basis of width. Typical forms and a slightly narrower form are otherwise in distinguishable and are tabulated together.

\section{Naviculopsis navicula (Ehrenberg) Deflandre} (Plate 8, Fig. 1)

Dictyocha navicula Ehrenberg, 1839, p. 129; Ehrenberg, 1854, pl. 20 (1), fig. 43.

Naviculopsis navicula (Ehrenberg) Deflandre, 1950, p. 107.

Naviculopsis navicula (Ehrenberg), Bukry, 1978b, p. 820 .

\section{Naviculopsis obtusarca Bukry}

(Plate 8, Figs. 2-7)

Eunaviculopsis strandneri Ling, new name, 1977, p. 214 [invalid basionym).

Naviculopsis obtusarca Bukry, 1978b, p. 821.

Remarks. The new name Eunaviculopsis strandneri proposed by

Ling (1977) cites as the basionym (first synonymy listing) a species

"Naviculopsis navicula Stradner (not Ehrenberg)," which appears as fig. 46 in Stradner (1961). This is an incorrect basionym because there is no legitimate formation or type for the name "Naviculopsis navicula Stradner" (ICBN, Art. 7, Note 4). Stradner's fig. 46 actually is identified as Naviculopsis navicula (Ehr.) Deflandre. Therefore the new name $E$. strandneri was based on an incorrect basionym and was not effectively published. Valid publication for $E$. strandneri would have required citation of a legitimate taxon for the basionym, such as Naviculopsis navicula (Ehrenberg) of Stradner, 1961 ... in the synonymy or text. No correction appeared prior to the effective publication of Naviculopsis obtusarca Bukry (1978b), which provided a name for the same species concept. This name was in press in 1976 and as such is an independent solution to the same taxonomic problem.

The specimen called N. ponticula for Leg 41 (Bukry, 1978, pl. 3, fig. 5) should be reclassified as $N$. sp. cf. $N$. obtusarca because of the narrowed apex aprons (see Plate 8, Figs. 6 and $8-10$, this chapter).

\section{Naviculopsis ponticula ponticula (Ehrenberg) Bukry}

(Plate 8, Figs. 11-12; Plate 9, Fig. 1)

Dictyocha ponticulus Ehrenberg, 1844b, p. 258, 267; Bailey, 1845, pl. 4 , fig. 21 .

not Naviculopsis ponticula Perch-Nielsen of Martini and Muller, 1976 , p. 873 , pl. 12 , figs. $1,2 .[=N$. punctilia Perch-Nielsen, 1976.]

Naviculopsis ponticula (Ehrenberg) Bukry, 1978b, p. 821, pl. 8, figs. 9, 10.

Naviculopsis ponticula (Ehrenberg), Bukry, 1980a (in part), p. 516, pl. 3 , figs. 1,3 (not 2 ).

\section{Naviculopsis quadrata (Ehrenberg) Ling}

Dictyocha quadrata Ehrenberg, 1844b, p. 258, 267; Bailey, 1845, fig. 22.

Naviculopsis quadrata (Ehrenberg) Ling, 1972, p. 187, pl. 31, fig. 2. Naviculopsis quadrata (Ehrenberg), Bukry, 1978b, p. 821, pl. 8, fig. 11.

Naviculopsis quadratum (Ehrenberg), Martini, 1979, p. 540, fig. 3 [excellent electromicrograph].

Genus OCTACTIS Schiller, 1926

Octactis pulchra Schiller

Octactis pulchra Schiller, 1926, p. 67, fig. C.

Octactis pulchra Schiller, Bukry, 1979b, p. 986, pl. 7, figs. 2, 3.

\section{SYSTEMATIC PALEONTOLOGY OF NEW TAXA}

\section{Genus CORBISEMA Hanna, 1928}

Corbisema triacantha (Ehrenberg) Hanna var. nuda Bukry, n. var. (Plate 1, Figs. 1-6)

Description. Corbisema triacantha var. nuda has a triangular ring with moderate spines at the corners. There is no apical system within the ring. Most specimens have only equant, short vestiges of the three struts that typically meet to form the triradiate apical structure of Corbisema. Other specimens have only two, one, or no vestiges of struts.

Remarks. Corbisema triacantha var. nuda is distinguished from Corbisema triacantha by the absence of a completed apical strut system. Instead of struts, vestigial stubs or a smooth ring are present.

Occurrence. Corbisema triacantha var. nuda occurs with normal specimens of Corbisema triacantha at eastern Pacific sites DSDP 469 and 495 in the middle Miocene part of the Corbisema triacantha Zone. The $18 \%$ abundance of $C$. triacantha var. nuda at DSDP 495 makes it especially conspicuous.

Size. Maximum inner diameter, 20 to $24 \mu \mathrm{m}$.

Holotype. USNM 309670 (Plate 1, Fig. 1).

Isotopes. USNM 309671 to 309675.

Type locality. Eastern North Pacific Ocean, DSDP Sample 49520-1, 100-102 cm.

\section{Genus DICTYOCHA Ehrenberg, 1837}

Dictyocha angulata Bukry, n. sp.

(Plate 1, Figs. 9-12; Plate 2, Fig. 1)

Description. Dictyocha angulata is moderate-sized and has a moderate apical bar aligned with the major axis. The struts are symmetric 
and the pikes are at or only slightly offset from the strut-ring junctions. The portals have angular (squared-off) margins. Major-axis spines are longer than minor axis spines. The ring is relatively wide; axial length-to-width ratios for the inner diameters range from 1.1 to 1.2 .

Remarks. Dictyocha angulata is distinguished from $D$. aegea by the wider format of the ring. Length-to-width ratios are only 1.1. or 1.2 , instead of 1.6 to 1.7 for $D$. aegea. Also, D. angulata lacks the obvious recurving of the side portals at the minor-axis spines. Further, specimens with auxiliary peripheral pikes were not observed.

Occurrence. Dictyocha angulata constitutes 7\% of lower Pliocene Sample $495-11-2,48-50 \mathrm{~cm}$ off Guatemala. A compared specimen from above in Sample 495-10-5, 50-52 cm, is more elongate (1.3). D. aegea, a possible descendant in the equatorial Pacific Ocean and Aegean Sea, is reported from the upper Pliocene by Stradner and Bachmann (1978) and Morlotti and Rio (1978 [1980]).

Size. Maximum inner diameter, 31 to $35 \mu \mathrm{m}$.

Holotype. USNM 309676 (Plate 1, Fig. 9)

Isotypes. USNM 309677 to 309680.

Type locality. Eastern North Pacific Ocean, DSDP Sample 495$11-2,48-50 \mathrm{~cm}$.

\section{Dictyocha delicata (Bukry) Bukry, n. comb.}

(Plate 2, Fig. 7)

Dictyocha perlaevis delicata Bukry, 1976c, p. 724, pl. 1, figs. 5-10. Dictyocha perlaevis delicata Bukry, 1980b, p. 552, pl. 3, figs. 8-12.

Remarks. Dictyocha delicata was originally described as a subspecies within the $D$. perlaevis group. The discovery of a new variation, D. delicata var. bisecta, at DSDP Site 495 prompted elevation in rank from subspecies to species for effective classification. $D$. delicata is recorded in upper Pliocene and Quaternary strata and ranges from DSDP Site 321 off Peru to DSDP Site 495 off Guatemala in the eastern Pacific.

\section{Dictyocha delicata (Bukry) Bukry var. bisecta Bukry, n. var.} (Plate 2, Figs. 3-6)

Description. Dictyocha delicata var. bisecta has struts and apical bar that are thinner than the ring. The bar is long, occupying $48 \%$ to $52 \%$ of the maximum inner diameter of the ring. The ring is a rounded rhomb showing little or no scalloping and no basal pikes. Spines are short.

Remarks. Dictyocha delicata var. bisecta is distinguished from $D$. delicata s. str. by the unscalloped basal ring, longer bar, and indistinct or missing basal pikes. The bar of $D$. delicata occupies $26 \%$ to $46 \%$ (usually $26 \%-33 \%$ ) of the maximum inner diameter.

Occurrence. Dictyocha delicata var. bisecta constitutes $21 \%$ of the assemblage in Pliocene Sample 495-10-5, 50-52 cm off Guatemala. It does not occur in higher or lower samples.

Size. Maximum inner diameter of ring, 32 to $38 \mu \mathrm{m}$.

Holotype. USNM 309681 (Plate 2, Fig. 3).

Isotypes. USNM 309682 to 309684.

Type locality. Eastern North Pacific Ocean, DSDP Sample 495$10-5,50-52 \mathrm{~cm}$

\section{Dictyocha longa Bukry, n. sp.}

(Plate 2, Figs. 8-13; Plate 3, Figs. 1-2)

Dictyocha perlaevis perlaevis Frenguelli, Bukry, 1980b (in part), p. 553 , pl. 4, figs. 10-13.

Description. Dictyocha longa is moderate-sized with a moderate to long apical bar aligned with the major axis. The struts are short and their angle to the bar is only slightly more than $90^{\circ}$, giving a nearly I-shaped appearance to the apical system. The ring is scalloped and narrow with inner-diameter length-to-width $(\mathrm{L} / \mathrm{W})$ ratios of 1.3 to 1.7 (average 1.5). Pikes are small and typically at or very near the strut junctions. Spines are moderate, the major-axis spines being about twice the length of the minor-axis spines.

Remarks. Dictyocha longa appears to be part of the Dictyocha fibula-Dictyocha perlaevis group. It is more scalloped than $D$. fib$u l a$, but less than $D$. perlaevis. $D$. longa is also distinguished from $D$. perlaevis by smaller size and more elongate format, with inner diameter length-to-width ratios averaging 1.5 , instead of only 1.2 for $D$. perlaevis (Bukry, 1980b, pl. 4). D. fibula s. str. from the Miocene (Bukry, 1978a, 1980a) also shows a L/W ratio of 1.1 to 1.3 and much less scalloping. $D$. longa is distinguished from elongate $D$. aegea by having rounded instead of squared-off portals.

Occurrence. Dictyocha longa appeared in the late late Miocene and was most numerous during the late late Miocene and early Pliocene. Occurrences in late Pliocene and early Quaternary are less numerous. Recorded as Dictyocha sp. cf. D. fibula (elongate) or D. sp. cf. D. perlaevis (elongate), it ranges from $16 \%$ to $40 \%$ in upper Miocene Core 10 at DSDP 471 and is noted as present in Core 8 at DSDP 470. Maximum abundances at DSDP 495 are $18 \%$ in Miocene, $34 \%$ in Pliocene, and $6 \%$ in Quaternary. Abundances up to $34 \%$ are recorded near the Pliocene/Pleistocene boundary of Pacific DSDP Site 425 in Core 6 (Bukry, 1980b). These initial occurrences are all in the eastern Pacific Ocean.

Size. Maximum inner diameter, 29 to $37 \mu \mathrm{m}$ (holotype $31 \mu \mathrm{m}$; average $31 \mu \mathrm{m}$ )

Holotype. USNM 309685 (Plate 2, Fig. 8).

Isotypes. USNM 309686 to 309692.

Type locality. Eastern North Pacific Ocean, DSDP Sample 495$9-3,50-52 \mathrm{~cm}$.

\section{Dictyocha longa Bukry var. paxilla Bukry, n. var.} (Plate 3, Figs. 3-8)

Description. Dictyocha longa var. paxilla possesses all of the characters of Dictyocha longa. It also has a moderate spire located at or near the center of the apical bar.

Remarks. Dictyocha longa var. paxilla is distinguished from $D$. longa by the presence of a spire. It is distinguished from spired species, such as $D$. aculeata and $D$. stapedia, by the symmetric or nearly symmetric format of the strut junctions, the elongation, scalloping of the ring, and greater proximity of pikes to strut junctions.

Occurrence. Dictyocha longa var. paxilla occurs in the upper Miocene and Pliocene of Cores 11 to 15 of DSDP 495 at abundances of $29 \%$ to $68 \%$. It was previously noted at DSDP 471 in the upper Miocene of Core 10 at abundances of only $3 \%$ to $6 \%$. It may be the earliest Neogene regular Dictyocha possessing a spire. Preliminary study of DSDP 77B shows $D$. longa present as the only spired Dictyocha in the upper Miocene Dictyocha neonautica Subzone.

Size. Maximum inner diameter, 30 to $38 \mu \mathrm{m}$; holotype $35 \mu \mathrm{m}$.

Holotype. USNM 309693 (Plate 3, Fig. 3).

Isotypes. USNM 309694 to 309698.

Type locality. Eastern North Pacific Ocean, DSDP Sample 495$11-2,48-50 \mathrm{~cm}$.

Dictyocha ornata ornata (Bukry), n. comb.

Dictyocha fibula Ehrenberg, Bukry and Foster, 1973 (in part), p. 826, pl. 2 , fig. 9

Dictyocha perlaevis ornata Bukry, 1977, p. 922, pl. 1, figs. 1-6.

not Dictyocha perlaevis ornata Bukry, Bukry, 1978d, p. 644, pl. 1, figs. 7,8 .

not Dictyocha perlaevis ornata Bukry, Bukry, 1979b, p. 984, pl. 3, figs. 4,5 .

Dictyocha perlaevis ornata Bukry, Bukry, 1979a, p. 561, pl. 2, figs. 11-14.

not Dictyocha perlaevis ornata Bukry, Bukry, 1980b, p. 552, pl. 4, figs. 1,2 .

Remarks. The original subspecies Dictyocha perlaevis ornata is elevated to species in order to recognize formally the differences in proportions between mid-Atlantic and western-Africa specimens (Bukry, 1979a). The original mid-Atlantic populations having nearly equal major and minor axes are Dictyocha ornata. The more elongate western-Africa morphology, with shorter minor axis spines, is recognized as a new subspecies.

Dictyocha ornata (Bukry) Bukry subsp. africana Bukry, n. subsp. (Plate 3, Fig. 11; Plate 4, Figs. 1-2)

Dictyocha perlaevis ornata Bukry, Bukry, 1978d, p. 644, pl. 1, figs. $7,8$.

Dictyocha perlaevis ornata Bukry, Bukry, 1979b, p. 984, pl. 3, figs. 4,5 .

Dictyocha perlaevis ornata Bukry, Bukry, 1980b, p. 522, pl. 4, figs. 1,2

Description. Dictyocha ornata africana is elongate with a long apical bar aligned with the major axis of the ring. The scalloped ring 
has two small, distally directed pikes on each of the four lobes. The major-axis spines are long, but the minor-axis spines are much shorter, frequently little longer than the distal pikes. Basal pikes are moderate to short and located near the struts.

Remarks. Dictyocha ornata africana is distinguished from Dictyocha ornata ornata by more elongate proportions, shorter minoraxis spines, and less sharply curved minor-axis portals. Although the specimens from DSDP Site 495 in the eastern Pacific have less pronounced characters than specimens from offshore Africa, they share the same major proportions. Their morphology is probably a response to upwelling near the coastal zone. Specimens lacking the full set of distal pikes on the major-axis portals at DSDP Site 495 are tabulated as $D$. sp. aff. $D$. ornata africana (Plate 4, Figs. 3 and 5).

Occurrence. Dictyocha ornata africana occurs at DSDP Legs 40, 47, 54, and 67, in areas of upwelling off Africa and Central America. The assemblages are upper Pliocene or lowest Quaternary.

Size. Maximum inner diameter of ring, 25 to $35 \mu \mathrm{m}$.

Holotypes. Plate 3, figure 5 of Bukry (1979b).

Isotypes. Plate 1, figure 8 of Bukry (1978d), and USNM 309699 to 309701.

Type locality. Western North Atlantic Ocean, DSDP Sample 397. $21-4,79-81 \mathrm{~cm}$.

Dictyocha subaculeata (Bukry), n. comb.

Dictyocha aculeata subaculeata Bukry, 1980b, p. 552, pl. 1, figs. 8-17.

Genus DISTEPHANUS Stöhr, 1880

Distephanus crux (Ehrenberg) Haeckel subsp. parvus (Bachmann) n. comb., emend. (Plate 4, Fig. 7)

Dictyocha crux Ehrenberg forma parva Bachmann in Ichikawa and others 1967 (in part), p. 156, pl. 4, figs. 14, 15, 19, 23?, 29-31. [Fig. 30 is the holotype.]

not Distephanus parvus (Bachmann) Bukry and Foster, 1973, p. 828, pl. 5, figs. 2, 3 [= Distephanus mesophthalmus].

Distephanus crux (Ehrenberg), Bukry, 1978a (in part), p. 697, pl. 2, figs, 8,9 (not fig. 7).

Distephanus crux (Ehrenberg), Bukry, 1980a, p. 514, pl. 2, fig. 8, 9 ?.

Remarks. Distephanus crux parvus is changed in rank from forma to subspecies on the basis of its distinctive morphology and widespread occurrence. It is emeneded to exclude specimens attributable to $D$. mesophthalmus and D. crux crux s. ampl. from the type suite and to permit moderate and small specimens to belong to the subspecies.

Bachmann showed both ovate- and square-outlined specimens in the type suite. He also showed specimens with and without four distal pikes on the apical ring. This broad concept for Distephanus crux parvus is herein restricted to the ovate specimen lacking apical pikes that was designated as the holotype by Bachmann. Following the usage of Dumitrică (1973b) and Bukry (1981), the specimens with apical pikes belong to $D$. mesophthalmus. The emended species is small to moderate in size.

Although it is not abundant at DSDP Site 495, D. crux parvus is common in the middle Miocene off West Africa at DSDP Sites 370 and 415 .

\section{Distephanus crux (Ehrenberg) Haeckel subsp. scutulatus Bukry, n. subsp.}

(Plate 4, Figs. 8-12; Plate 5, Figs. 1-2; Plate 9, Fig. 8)

Description. Distephanus crux scutulatus has a moderate to large, elongated, angular, rhomb-shaped basal ring and a moderate, square apical ring. Basal pikes are small and well offset from strut junctions. Spines are moderate to long, and the sides of the basal ring are essentially straight. Strut junction positions are only slightly rotated from bisecting the sides of the basal ring. The elongation of the ring, measured by the length-to-width ratio of inner diameters, is 1.2 to $1.4(1.3$ average). The major-axis inner diameter is longer than either of the major spines.

Remarks. Distephanus crux scutulatus is distinguished from Distephanus crux (see Loeblich et al., 1968) by a combination of characteristics, including more consistent and greater elongation, larger apical ring, and more difference between major and minor spine lengths. Elongation of the rhomb-shaped basal ring is distinctive. $D$. crux scutulatus is distinguished from $D$. crux parvus by the straighter sides of the basal ring and generally smaller apical ring, and from $D$. longispinus by spines that are shorter than the maximum ring length.

Occurrence. Distephanus crux scutulatus is found in the lower and middle Miocene at DSDP Site 495 , Cores 20 to 33, where it may dominate with abundance up to $82 \%$.

Size. Maximum inner diameter, 28 to $34 \mu \mathrm{m}$; holotype $29 \mu \mathrm{m}$.

Holotype. USNM 309702 (Plate 4, Fig. 9).

Isotypes. USNM 309703 to 309708 and 309739.

Type locality. Eastern North Pacific Ocean, DSDP Sample 495$33-4,48-50 \mathrm{~cm}$.

\section{Distephanus polyactis (Ehrenberg) Deflandre var. literatus Bukry, n. var.}

(Plate 5, Fig. 4)

Description. The single, large, obscured specimen of Distephanus polyactis var. literatus has an unusual bar and strut structure, like Dictyoch a fibula, within the large apical ring. The apical ring is separated from the zigzag basal ring by a circlet of 11 portals of pentagonal, and a few of hexagonal, form. There is a short spine on the basal ring at the apex of each portal.

Remarks. Distephanus polyactis var. literatus is distinguished from $D$. polyactis by a zigzag basal ring and a fibuloid apical bar system within the apical ring, and from D. rosae (see Perch-Nielsen, 1976) by the apical bar system.

A sketch (Fig. 3) is provided because of the obscured and tilted nature of the photographic specimen.

Occurrence. Distephanus polyactis var. literatus is known only from DSDP Site 495, Core 14, which is assigned to the upper Miocene Dictyocha neonautica Subzone. Distephanus rosae, the most structurally similar form, is from the upper Eocene of the Norwegian Sea.

Size. Maximum internal diameter, $77 \mu \mathrm{m}$.

Holotype. USNM 309709 (Plate 5, Fig. 4).

Type locality. Eastern North Pacific Ocean, DSDP Sample 495$14-2,20-22 \mathrm{~cm}$.

\section{Distephanus speculum (Ehrenberg) Haeckel subsp. patulus Bukry, n. subsp. \\ (Plate 5, Figs. 7-10)}

Distephanus speculum speculum (Ehrenberg), Bukry, 1978c, p. 786, pl. 2, figs. $13,14$.

Distephanus speculum speculum (Ehrenberg) s. ampl., Bukry, 1980a, p. 514 , pl. 2, fig. 12 .

Description. Distephanus speculum patulus has a regular hexagonal basal ring with short spines and pikes. The apical ring is a large, well-elevated regular hexagon. Major axis spines are only slightly

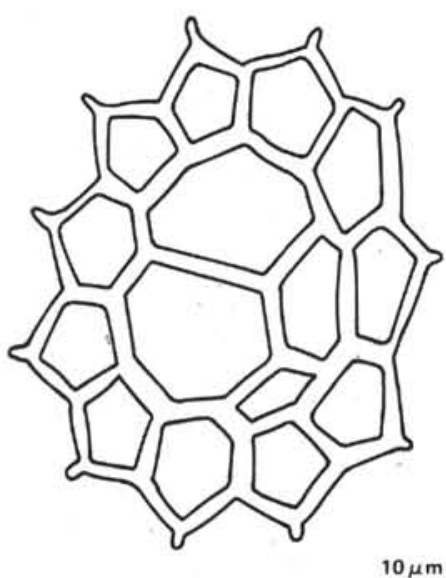

Figure 3. Tracing of Distephanus polyactis var. literatus Bukry, n. var. (Scale bar equals $10 \mu \mathrm{m}$.) 
longer than the other spines. Basal-ring length-to-width ratios are 1.1 to 1.3 (average 1.2). The ratios between the basal and apical rings along the minor axis are 1.3 to 1.8 (average 1.7 ).

Remarks. Distephanus speculum patulus is distinguished from $D$. speculum speculum by short axial spines nearly equal to other spines and a large hexagonal apical ring (see Loeblich et al., 1968, pl. 24; and Locker, 1974, pl. 3). It is distinguished from $D$. speculum minutus by having short, nearly equant spines. It is distinguished from irregular D. pauliani fa. hexagona, on the basis of the holotypes, by larger apical ring, consistently regular and symmetric hexagonal ring form, and less elongation of the basal ring. The length-to-width ratio for $D$. speculum patulus is only 1.1 to 1.3 (1.2 average), whereas $D$. pauliani has 2.1 for its holotype and the illustrated range of 1.2 to 2.1 (average 1.4 ) for the suite. Both $D$. speculum minutus and D. pauliani fa. hexagona are later developments of the genus from the upper Miocene.

Occurrence. Distephanus speculum patulus occurs in Oligocene to middle Miocene strata cored at DSDP Sites 385 and 415 in the Atlantic Ocean and at DSDP Site 495 in the Pacific.

Size. Maximum inner diameter, 27 to $41 \mu \mathrm{m}$ (holotype $30 \mu \mathrm{m}$; average $34 \mu \mathrm{m}$ ).

Holotype. USNM 309710 (Plate 5, Fig. 7).

Isotypes. USNM 309711 to 309713.

Type locality. Eastern North Pacific Ocean, DSDP Sample 495$32-5,48-50 \mathrm{~cm}$.

\section{Genus NAVICULOPSIS Frenguelli, 1940 Naviculopsis contraria Bukry, n. sp. (Plate 6, Figs. 5-13)}

Description. Naviculopsis contraria has two moderate to long axial spines, one of which may be slightly tilted off-line from the major axis. The ring is ellipsoidal to elongate-oblong with a tendency to be slightly bowed out at the junction of the apical band; ends are rounded. The band is of moderate width, typically equaling about a half of the width of the short-axis inner diameter of the ring. The band flares only slightly at the junctions. Although the sides of the ring and the spines appear tubular, the ring is flat at the ends, forming an apron between the spines and main length of the ring. Sparse specimens have a short apical spire.

Remarks. Naviculopsis contraria is distinguished from N. constricta (see Ling, 1972; Bukry, 1975b, 1976a) by the flat, nontubular area at the ends of the basal ring. The greater tendency to be bowedout near the band and the relatively shorter axial spines also contribute to the distinction.

Occurrence. Naviculopsis contraria is known only from DSDP Sample $495-31-5,48-50 \mathrm{~cm}$, where it constitutes $78 \%$ of the population. This is an early Miocene sample assigned to the Naviculopsis ponticula Zone. Other samples from Sections 1 and 3 of Core 31 belong to the coccolith Sphenolithus belemnos Zone.

Size. Maximum inner diameter, 34 to $41 \mu \mathrm{m}$ (holotype $40 \mu \mathrm{m}$; average $39 \mu \mathrm{m}$ ).

Holotype. USNM 309714 (Plate 6, Fig. 5).

Isotypes. USNM 309715 to 309722.

Type locality. Eastern North Pacific Ocean, DSDP Sample 495$31-5,48-50 \mathrm{~cm}$.

Naviculopsis lacrima Bukry, n. sp.

(Plate 7, Figs. 1-10; Plate 9, Fig. 8)

Description. Naviculopsis lacrima has two slender, moderately long, axial spines, one of which may be slightly curved. The basal ring has a long narrow biconvex outline with acutely pointed ends. The apical band is moderately wide at half the width (or slightly greater than half the width) of the ring opening; the margins of the band are concavo-concave, resulting in a moderately to strongly flared junction with the ring. There is no perceptible constriction of the ring at the junction. The ends of the ring may show very small but nonsystematic flattening of the tube structure. Spine length is equal to or slightly less than one half of the maximum inner diameter.

Remarks. Naviculopsis lacrima is distinguished from $N$. contraria by the unusual teardrop-shaped portals formed by acute ring terminations and concave band margin. The lack of systematic flattened ring ends is also distinctive. Similarly, it is distinguished from $N$. constricta by greater flare of the band, more acute ring ends, and convex ring sides (see Ling, 1972; Bukry, 1975b, 1976a).
Because $N$. lacrima occurs in a deeper level at the same site as $N$. constricta and shares comparable structural elements, such as the apical band, it is likely that the two species belong to the same evolutionary lineage.

Occurrence. Naviculopsis lacrima is known only from DSDP Site 495 in lower Miocene strata assigned to the lower Naviculopsis ponticula Zone. It is abundant $(66 \%)$ in Core 32 but is only a minor $(5 \%)$ part of the assemblage above in Core 31 where $N$. contraria dominates.

Size. Maximum inner diameter, 40 to $56 \mu \mathrm{m}$ (holotype $48 \mu \mathrm{m}$; average $46 \mu \mathrm{m})$.

Holotype: USNM 309723 (Plate 7, Fig. 3).

Isotypes: USNM 309724 to 309733.

Type locality. Eastern North Pacific Ocean, DSDP Sample 495$32-2,48-50 \mathrm{~cm}$.

Naviculopsis lata (Deflandre) Frenguelli var. obliqua Bukry, n. var. Naviculopsis sp. cf. N. lata (Deflandre), Ling 1977, p. 214, pl. 3, fig. 12.

Naviculopsis cf. lata (Defl.) Freng., Sawamura and Otowa, 1979, p. 52 , fig. 2 (13).

Description. Naviculopsis lata var. obliqua has a wide, roundedoblong ring with two moderate to short spines. The bar spanning the ring is symmetrically oriented and essentially perpendicular $\left(81^{\circ}-87^{\circ}\right)$ to the major axis of symmetry of the ring. The axis of the spines, however, is canted $20^{\circ}$ to $21^{\circ}$ from the major axis of the ring and $60^{\circ}$ to $67^{\circ}$ from the bar direction, as determined from the type suite. This canting of both the ring axis and bar, with respect to the spine axis, produces an unusual pattern. The two spines constitute $30 \%$ to $36 \%$ of the total length, and the exterior length-to-width ratio along the ring axes of symmetry is 1.37 .

Remarks. Naviculopsis lata var. obliqua is distinguished from $N$. lata by the canted orientation between the spine axis and the bar and ring axes. It is distinguished from $N$. robusta by the same canted symmetry and the lack of triangular plates near the bar-ring junctions.

Occurrence. Two nearly identical specimens of Naviculopsis lata var. obliqua have been recently illustrated from the lower Miocene Naviculopsis quadrata Zone of Japan (Sawamura and Otowa, 1979) and from the upper Pleistocene (reworked specimen?) of Gulf of Alaska DSDP Site 179 (Ling, 1977). Therefore the known range is within the North Pacific. N. lata var. obliqua is probably from the lower Miocene, where typical $N$. lata is most abundant.

Size. Maximum width 32 to $38 \mu \mathrm{m}$.

Holotype. Figure 2 (13) of Sawamura and Otowa (1979).

Isotype. Plate 3, figure 12 of Ling (1977).

Type locality. Sample No. 3 of Sawamura and Otowa (1979).

\author{
Naviculopsis ponticula (Ehrenberg) Bukry subsp. spinosa \\ Bukry, n. subsp. \\ (Plate 9, Figs. 2-6)
}

Naviculopsis ponticula (Ehrenberg), Bukry, 1980a (in part), p. 516, pl. 3 , fig. 2 (spined).

Description. Naviculopsis ponticula spinosa has two uniformly short axial, tubular spines that are up to about half as long as the apical bar. The basal ring is elongate-oblong and large; its ends are fairly broad with rounded corners. The sides of the ring are subparallel, with some concaveness at the bar junctions. The inner diameter length-to-width ratio of the ring is 3.4 to 4.3 (average 3.8). The ends of the ring are uniformly flat instead of tubular, forming a hyaline apron, like Naviculopsis ponticula.

Remarks. Naviculopsis ponticula spinosa is distinguished from $N$. ponticula by the systematic occurrence of short tubular axial spines. It is distinguished from N. contraria by shorter spines and apical bar.

Occurrence. Naviculopsis ponticula spinosa was first recorded as sparse at DSDP Hole 416A in the Atlantic Ocean off West Africa in lower or middle Miocene strata (Bukry, 1980a). At DSDP Site 495 in the Pacific Ocean off Guatemala, it constitutes up to $18 \%$ of the assemblage in a lower Miocene sample near the top of the range of the genus Naviculopsis (Sample 495-31-1, 48-50 cm). Coccoliths of this sample belong to the Sphenolithus belemnos Zone.

Size. Maximum inner diameter, 55 to $65 \mu \mathrm{m}$ (holotype $59 \mu \mathrm{m}$; average $59 \mu \mathrm{m}$ ).

Holotype. USNM 309734 (Plate 9, Fig. 2).

Isotypes. USNM 309735 to 309738 . 
Type locality. Eastern North Pacific Ocean, DSDP Sample 495$31-1,48-50 \mathrm{~cm}$.

\section{ACKNOWLEDGMENTS}

I thank the Co-chief Scientists, Roland von Huene, U.S. Geological Survey, and Jean Aubouin, Université Pierre et Marie Curie, and the shipboard scientists of Leg 67 for making samples available for a shore-laboratory study of silicoflagellates. During the study, Jean Westberg, Scripps Institution of Oceanography, provided valuable radiolarian correlations; Nikita Muzylöv, U.S.S.R. Academy of Sciences, shared his results on coccolith zonation; and John Barron and Richard Poore, U.S. Geological Survey, gave helpful insights on Pacific Neogene paleoclimatology. I thank Dorothy Blackstock, U.S. Geological Survey, for typing, coordinating, and proofing the manuscript for consistency. John Barron and Richard Poore provided constructive technical reviews that improved the paper.

\section{REFERENCES}

Bailey, J. W., 1845. Notice of some new localities of Infusoria, fossil and Recent. Am. J. Sci., 48:321-343.

Bukry, D., 1975a. Coccolith and silicoflagellate stratigraphy, northwestern Pacific Ocean, Deep Sea Drilling Project Leg 32. In Larson, R. L. Moberly, R., et al., Init. Repts. DSDP, 32: Washington (U.S. Govt. Printing Office), 677-701.

, 1975b. Silicoflagellate and coccolith stratigraphy, Deep Sea Drilling Project Leg 29. In Kennett, J. P., Houtz, R. E., et al., Init. Repts. DSDP, 29: Washington (U.S. Govt. Printing Office), 845-872.

1976a. Cenozoic silicoflagellate and coccolith stratigraphy, South Atlantic Ocean, Deep Sea Drilling Project Leg 36. In Hollister, C. D., Craddock, C., et al., Init. Repts. DSDP, 35: Washington (U.S. Govt. Printing Office), 885-917.

1976b. Silicoflagellate and coccolith stratigraphy, Norwegian-Greenland Sea, Deep Sea Drilling Project Leg 38. In Talwani, M., Udintsev, G., et al., Init. Repts. DSDP, 38: Washington (U.S. Govt. Printing Office), 843-855.

1976c. Silicoflagellate and coccolith stratigraphy, southeastern Pacific Ocean, Deep Sea Drilling Project Leg 34. In Yeats, R. S., Hart, S. R., et al., Init. Repts. DSDP, 34: Washington (U.S. Govt. Printing Office), 715-735.

1977. Coccolith and silicoflagellate stratigraphy, central North Atlantic Ocean, Deep Sea Drilling Project Leg 37. In Aumento, F., Melson, W. G., et al., Init. Repts. DSDP, 37: Washington (U.S. Govt. Printing Office), 917-927.

,1978a. Cenozoic coccolith and silicoflagellate stratigraphy, offshore northwest Africa, Deep Sea Drilling Project Leg 41. In Lancelot, Y., Seibold, E., et al., Init. Repts. DSDP, 41: Washington (U.S. Govt. Printing Office), 689-707.

1978b. Cenozoic coccolith, silicoflagellate, and diatom stratigraphy, Deep Sea Drilling Project Leg 44. In Benson, W. E., Sheridan, R. E., et al., Init. Repts. DSDP, 44: Washington (U.S. Govt. Printing Office), 807-863.

1978c. Cenozoic silicoflagellate and coccolith stratigraphy, northwestern Atlantic Ocean, Deep Sea Drilling Project Leg 43. In Benson, W. E., Sheridan, R. E., et ai., Init. Repts. DSDP, 44: Washington (U.S. Govt. Printing Office), 775-805.

, 1978d. Cenozoic silicoflagellate and coccolith stratigraphy, southeastern Atlantic Ocean, Deep Sea Drilling Project Leg 40. In Bolli, H. M., Ryan, W. B. F., et al., Init. Repts. DSDP, 40: Washington (U.S. Govt. Printing Office), 635-649.

, 1979a. Coccolith and silicoflagellate stratigraphy, northern Mid-Atlantic Ridge and Reykjanes Ridge, Deep Sea Drilling Project Leg 49. In Luyendyk, B. P., Cann, J. R., et al., Init. Repts. DSDP, 49: Washington (U.S. Govt. Printing Office), 551-581. $1979 \mathrm{~b}$. Comments on opal phytoliths and stratigraphy of Neogene silicoflagellates and coccoliths at Deep Sea Drilling Project Site 397 off northwest Africa. In Luyendyk, B. P., Cann, J. R., et al., Init. Repts. DSDP, 49: Washington (U.S. Govt. Printing Office), 977-1009.

1980a. Miocene Corbisema triacantha Zone phytoplankton from Deep Sea Drilling Project Sites 415 and 416, off northwest Africa. In Lancelot, Y., Winterer, E. L., et al., Init. Repts. $D S D P, 50$ : Washington (U.S. Govt. Printing Office), 507-523. 1980b. Silicoflagellate biostratigraphy and paleoecology in the eastern equatorial Pacific, Deep Sea Drilling Project Leg 54. In Hekinian, R., Rosendahl, B. R., et al., Init. Repts. DSDP, 54: Washington (U.S. Govt. Printing Office), 545-573.

1981. Silicoflagellate stratigraphy of offshore California and Baja California, Deep Sea Drilling Project Leg 63. In Yeats, R. S., Haq, B. U., et al., Init. Repts. DSDP, 63: Washington (U.S. Govt. Printing Office), 539-557.

, in press. Synthesis of silicoflagellate stratigraphy for Maestrichtian to Quaternary marine sediment. Soc. Econ. Paleontol. Mineral. Spec. Publ.

Bukry, D., and Foster, J. H., 1973. Silicoflagellate and diatom stratigraphy, Leg 16, Deep Sea Drilling Project. In van Andel, Tj. H., Heath, G. R., et al., Init. Repts. DSDP, 16: Washington (U.S. Govt. Printing Office), 815-871.

Ciesielski, P. F., 1975. Biostratigraphy and paleoecology of Neogene and Oligocene silicoflagellates from cores recovered during Antarctic Leg 28, Deep Sea Drilling Project. In Hayes, D. E., Frakes, L. A., et al., Init. Repts. DSDP, 28: Washington (U.S. Govt. Printing Office), 625-691.

Deflandre, G., 1932. Sur la systématique des Silicoflagellés. Soc, Bot. Fr. Bull., 79:494-506.

, 1950. Contribution a l'étude des silicoflagellidés actuels et fossiles. Microscopie, 2:72-108, 117-142, and 191-210.

Douglas, R. G., and Savin, S. M., 1973. Oxygen and carbon isotope analyses of Cretaceous and Tertiary foraminifera from the central North Pacific. In Winterer, E. L., Ewing, J. I., et al., Init. Repts. DSDP, 17: Washington (U.S. Govt. Printing Office), 591-605.

Dumitricǎ, P., 1973a. Miocene and Quaternary silicoflagellates in sediments from the Mediterranean Sea. In Ryan, W. B. F., Hsü, K. J., et al., Init. Repts. DSDP, 13: Washington (U.S. Govt. Printing Office), 902-933.

1973b. Paleocene, late Oligocene and post-Oligocene silicoflagellates in southwestern Pacific sediments cored on DSDP Leg 21. In Burns, R. E., Andrews, J. E., et al., Init. Repts. DSDP, 21: Washington (U.S. Govt. Printing Office), 837-883.

Ehrenberg, C. G., 1839. Über die Bildung der Kreidefelsen und des Kreidemergels durch unsichtbare Organismen. K. Preuss. Akad. Wiss. Berlin Ber., Jahrg. 1838:59-148.

1840. 274 Blatter von ihm selbst ausgefuhrter Zeichnungen von ebenso vielen Arten. K. Preuss. Akad. Wiss. Berlin Ber., Jahrg. 1840:197-219 (Nov.).

1844a. Mittheilung uber zwei neue Lager von Gebirgsmassen aus Infusorien als Meeres-Absatz in Nord-Amerika und eine Vergleichung derselben mit den organischen Kreide-Gebilden in Europa und Afrika. K. Preuss. Akad. Wiss. Berlin Ber., Jahrg. 1844:57-97.

, 1844b. Untersuchungen über die kleinsten Lebensformen im Quellenlande des Euphrats und Araxes, so wie über eine an neuen Formen sehr reiche marine Tripelbildung von den BermudaInseln vor. K. Preuss. Akad. Wiss. Berlin Ber., Jahrg. 1844: 253-275.

1854. Mikrogeologie: Leipzig (Leopold Voss), pp. 1-374.

Frenguelli, J., 1940. Consideraciones sobre los silicoflagelados fósiles. Mus. La Plata Rev., Paleontol., 2(7):37-112.

1951. Silicoflagelados del Trípoli de Mejillones (Chile). Physis (Buenos Aires), 20:272-284.

Haeckel, E. H. P. A., 1887. Cannorrhaphida. Challenger Rep., 18: 1546-1569.

Hanna, G. D., 1931. Diatoms and silicoflagellates of the Kreyenhagen shale. Calif. Div. Mines Geol. State Mineral. Rep., 27:187-201.

Ichikawa, W., Shimizu, I., and Bachmann, A., 1967. Fossil silicoflagellates and their associated uncertain forms in Iida Diatomite, Noto Peninsula, Central Japan. Sci. Rep. Kanazawa Univ., 12: 143-172.

Jerković, L., 1965. Sur quelques silicoflagellides de Yugoslavie. Lab. Micropaleont., Inst. Paleont. Museum: Paris, pp. 1-8.

Keller, G., 1980. Middle to late Miocene planktonic foraminiferal datum levels and paleoceanography of the North and Southeastern Pacific Ocean. Mar. Micropaleontol., 5:249-281.

Lemmermann, E., 1901. Silicoflagellatae. Deutsche. Bot. Ges. Ber., 19:247-271.

Ling, H. Y., 1972. Upper Cretaceous and Cenozoic silicoflagellates and ebridians. Bull. Am. Paleontol., 62:135-229. 
1977. Late Cenozoic silicoflagellates and ebridians from the eastern North Pacific region. Proc. First Int. Congr. Pacific Neogene Stratigraphy: Tokyo, pp. 205-233.

Locker, S., 1974. Revision der Silicoflagellaten aus der Mikrogeologischen Sammlung von C. G. Ehrenberg. Eclogae Geol. Helv., 67:631-646.

Loeblich, A. R., III, Loeblich, L. A., Tappan, H., and Loeblich, A. R., Jr., 1968. Annotated index of fossil and recent silicoflagellates and ebridians with descriptions and illustrations of validly proposed taxa. Geol. Soc. Am. Mem., 106:1-319.

Martini, E., 1979. Calcareous nannoplankton and silicoflagellate biostratigraphy at Reykjanes Ridge, northeastern North Atlantic (DSDP Leg 49, Sites 407 and 409). In Luyendyk, B. P., Cann, J. R., et al., Init. Repts. DSDP, 49: Washington (U.S. Govt. Printing Office), 533-549.

Martini, E., and Müller, C., 1976. Eocene to Pleistocene silicoflagellates from the Norwegian-Greenland Sea (DSDP Leg 38). In Talwani, M., Udintsev, G., et al., Init. Repts. DSDP, 38: Washington (U.S. Govt. Printing Office), 857-895.

Morlotti, E., and Rio, D., 1978 [1980]. Silicoflagellates, ebridians and actiniscids from Le Castella Section (Calabria, Southern Italy). Ateneo Parmense Acta Nat., 14:95-118.
Perch-Nielsen, K., 1976. New silicoflagellates and a silicoflagellate zonation in north European Palaeocene and Eocene diatomites. Bull. Geol. Soc. Den., 25:27-40.

Poelchau, H. S., 1976. Distribution of Holocene silicoflagellates in North Pacific sediments. Micropaleontology, 22:164-193.

Sawamura, K., and Otowa, K., 1979. Silicoflagellates flora in calcareous concretions found in Cretaceous and Tertiary of Japan. Jpn. Geol. Surv. Bull., 30:51-56.

Schiller, J., 1926. Die planktontischen Vegetation des adriatischen Meers.: B. Chrysomonadina, Heterokontae, Cryptomonadina, Eugleninae, Volvocales. 1. Systematischer Teil. Arch. Protistenkd., 53:59-123.

Schulz, P., 1928. Beiträge zur Kenntnis fossiler und rezenter Silicoflagellaten. Bot. Arch., 21:225-292.

Stradner, H., 1961. Über fossile Silicoflagelliden und die Möglichkeit ihrer Verwendung in der Erdölstratigraphie. Erdöel Kohle, 14: 87-92.

Stradner, H., and Bachmann, A., 1978. Late Pliocene and early Pleistocene silicoflagellates and ebridians from DSDP Site 378 in the Aegean Basin, north of Crete. In Hsü, K. J., Montadert, L., et al., Init. Repts. DSDP, 42, Pt. 1: Washington (U.S. Govt. Printing Office), 805-815. 


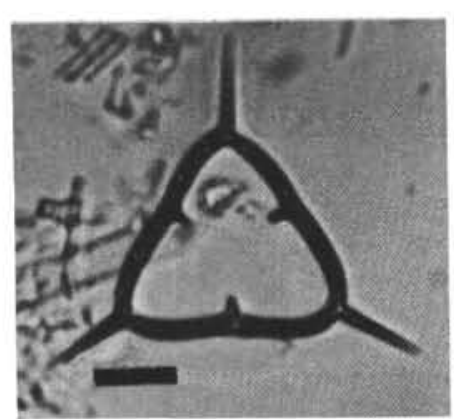

1

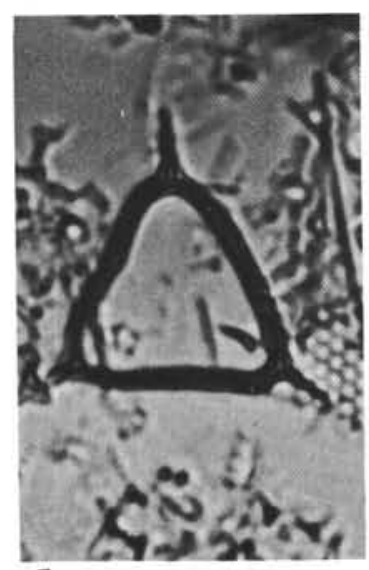

5

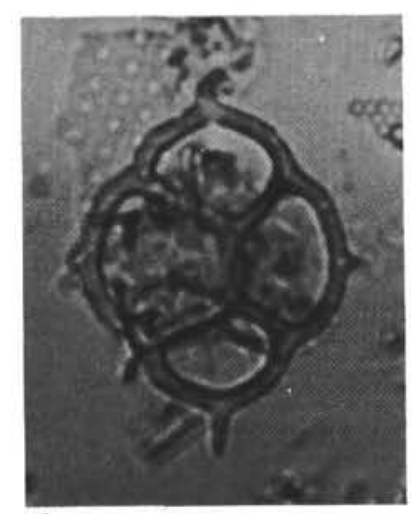

9

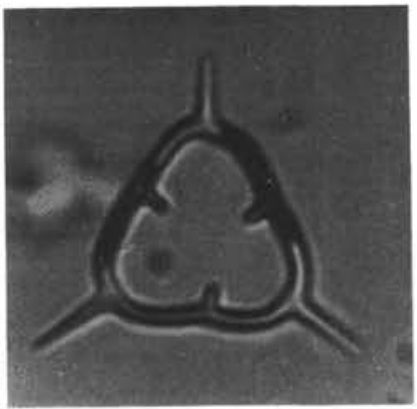

2

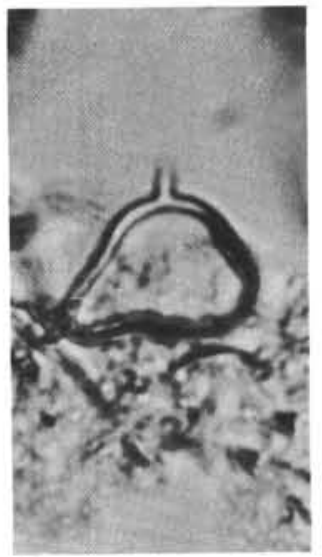

6

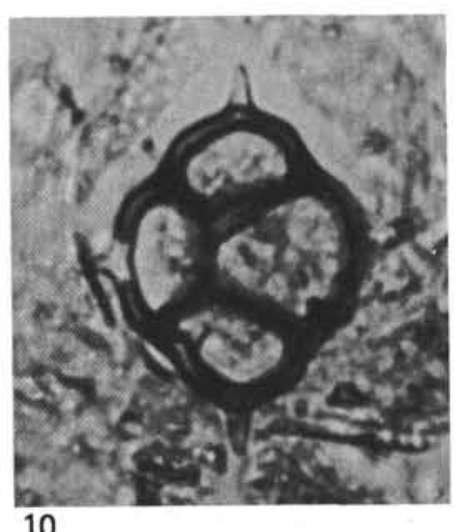

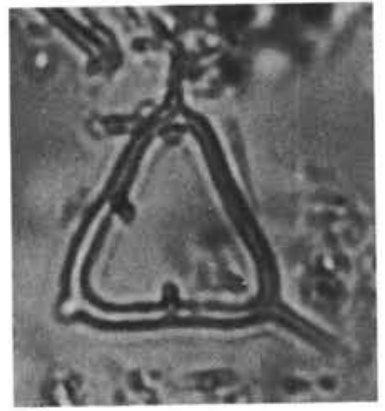

3
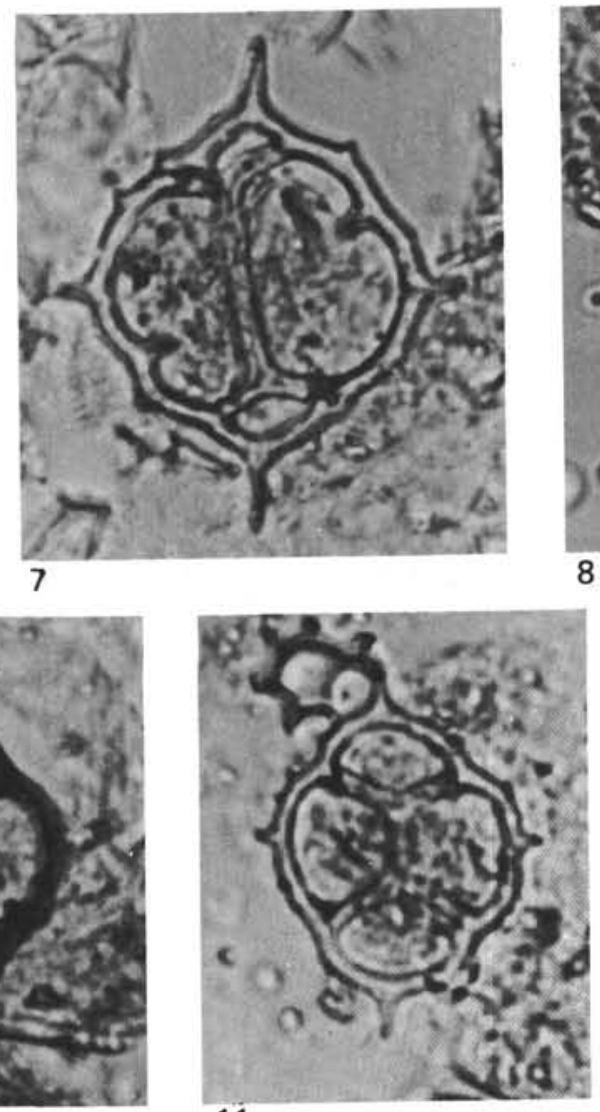

11
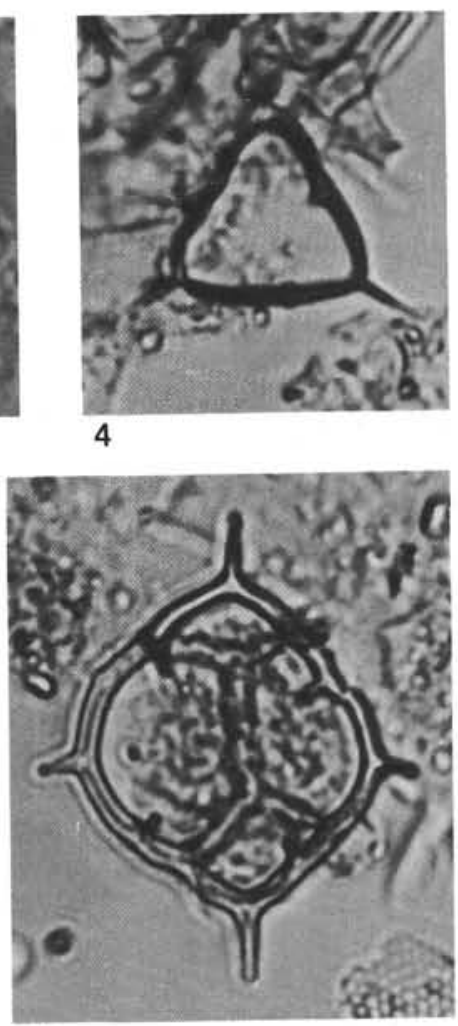

8

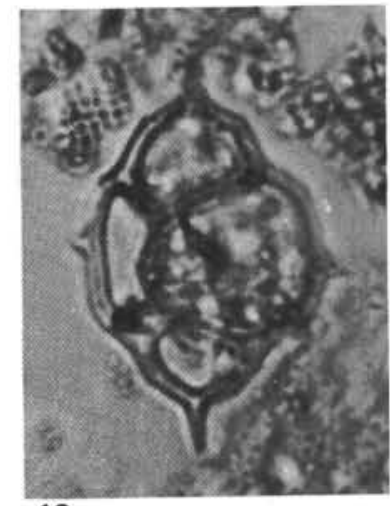

12

Plate 1. Silicoflagellates from DSDP Site 495. (Magnification $800 \times$; scale bar equals $10 \mu \mathrm{m}$.) 1-6. Corbisema triacantha (Ehrenberg) var. nuda Bukry, n. var. All specimens are from Sample 495-20-1, 100-102 cm. (1) Holotype, USNM 309670, (2) USNM 309671, (3) USNM 309672, (4) USNM 309673, (5) USNM 309674, (6) USNM 309675, tilted. 7. Dictyocha aculeata (Lemmermann). Long-barred. Sample 495-3-1, 55-57 cm. 8. Dictyocha sp. aff. D. aculeata (Lemmermann). Rounded ring. Sample 495-3-1, 55-57 cm. 9-12. Dictyocha angulata Bukry, n. sp. All specimens are from Sample 495-11-2, 48-50 cm. (9) Holotype, USNM 309676, (10) USNM 309677, (11) USNM 309678, (12) USNM 309679, tilted. 


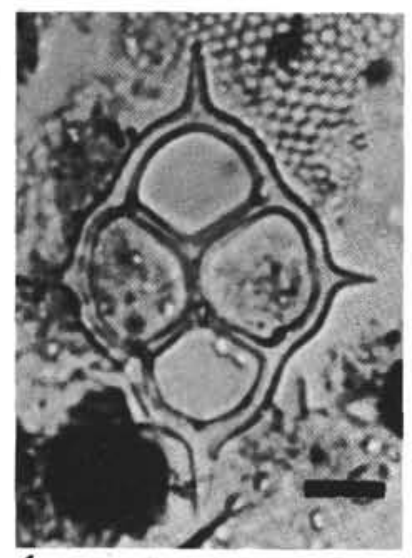

1

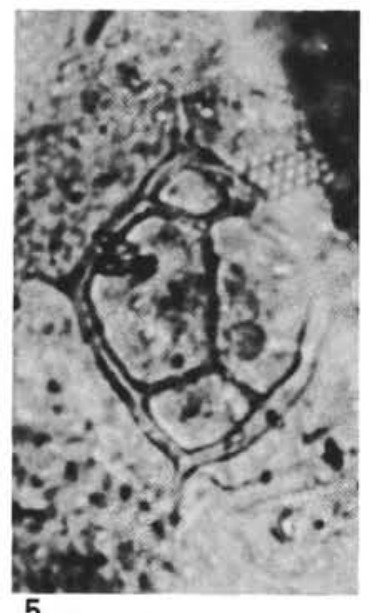

5

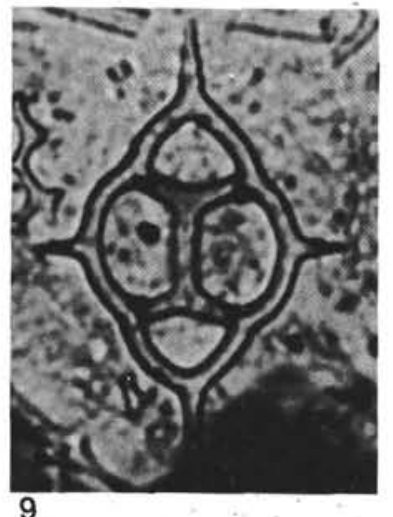

9

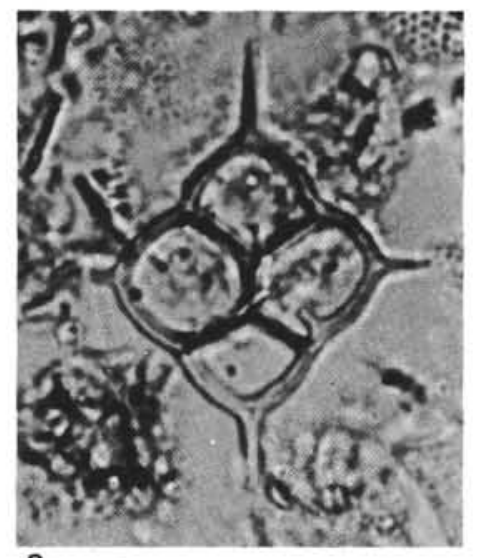

2

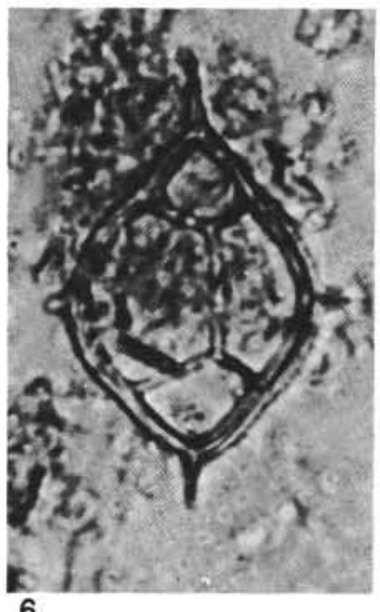

6

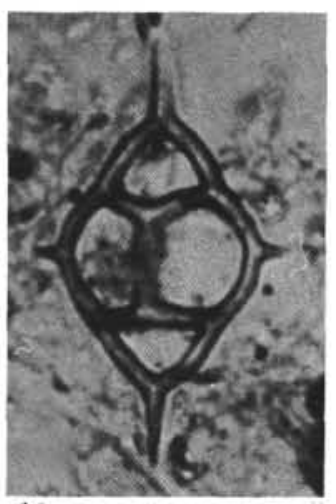

10

7

11
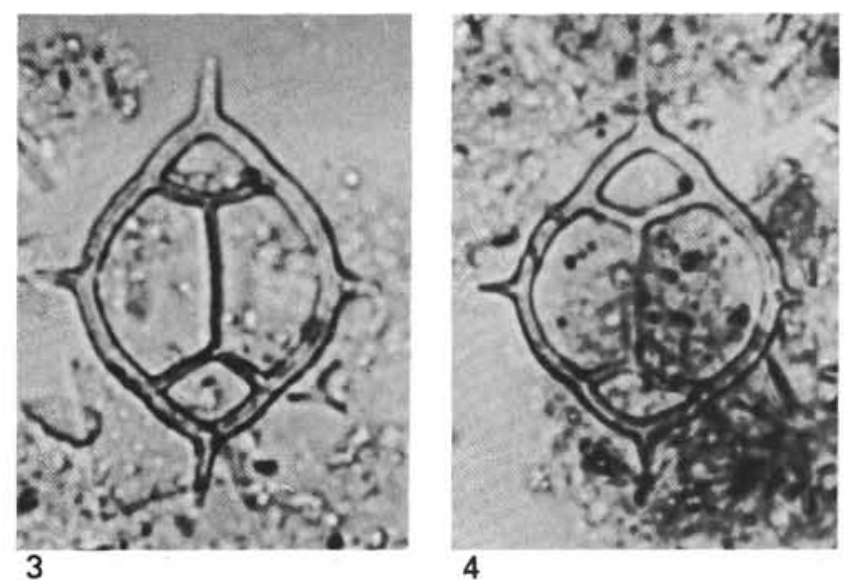

4
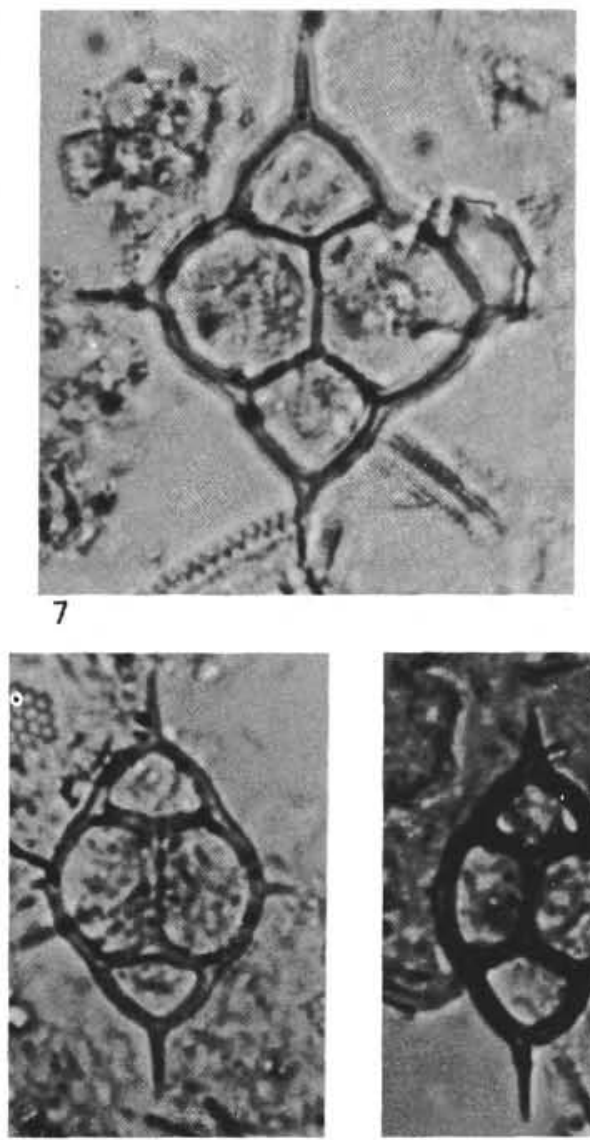

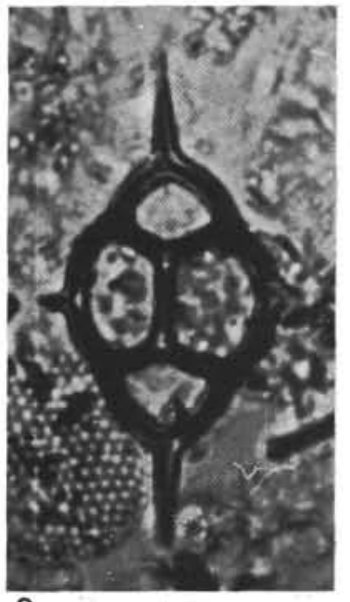

8

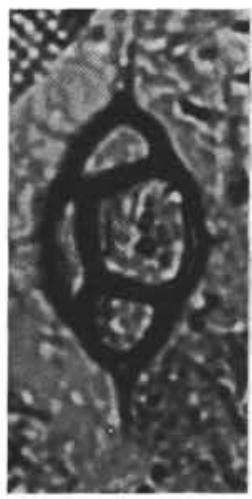

13

Plate 2. Silicoflagellates from DSDP Site 495. (Magnification $800 \times$; scale bar equals $10 \mu \mathrm{m}$.) 1. Dictyocha angulata Bukry, n. sp., s. ampl. USNM 309680, Sample 495-10-5, 50-52 cm. 2. Dictyocha calida calida Poelchau. Sample 495-17-2, 50-52 cm. 3-6. Dictyocha delicata var. bisecta Bukry, n. var. All specimens are from Sample 495-10-5, 50-52 cm. (3) Holotype, USNM 309681, (4) USNM 309682, (5) USNM 309683, (6) USNM 309684. 7. Dictyocha delicata (Bukry). Sample 495-6-3, 50-52 cm. 8-13. Dictyocha longa Bukry, n. sp. (8) Holotype, USNM 309685, Sample 495-9-3, 50-52 cm, (9) USNM 309686, Sample 495-9-3, 50-52 cm, (10) USNM 309687, Sample 495-11-2, 48-50 cm, (11) USNM 309688, Sample 495-11-2, 48-50 cm, (12) USNM 309689, Sample 495-9-3, 50-52 cm, (13) USNM 309690, Sample 495-9-3, 50-52 cm. 


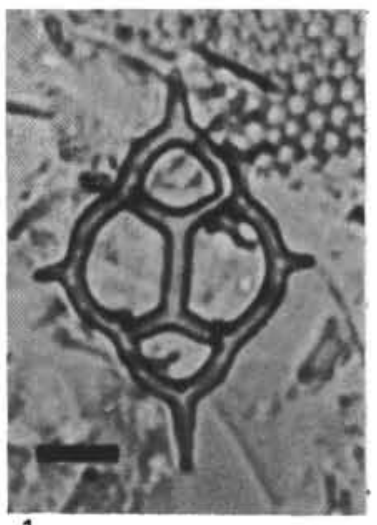

1

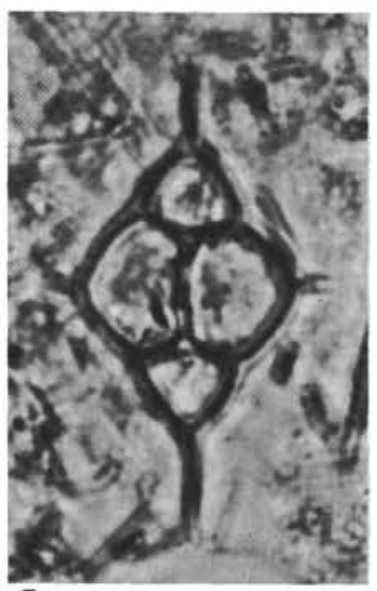

5

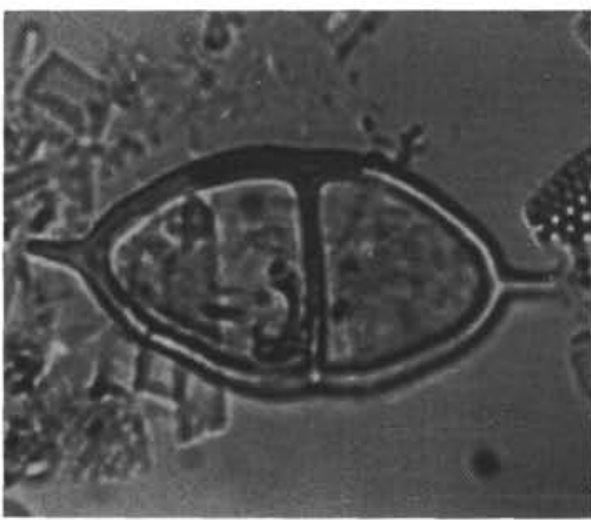

9

2
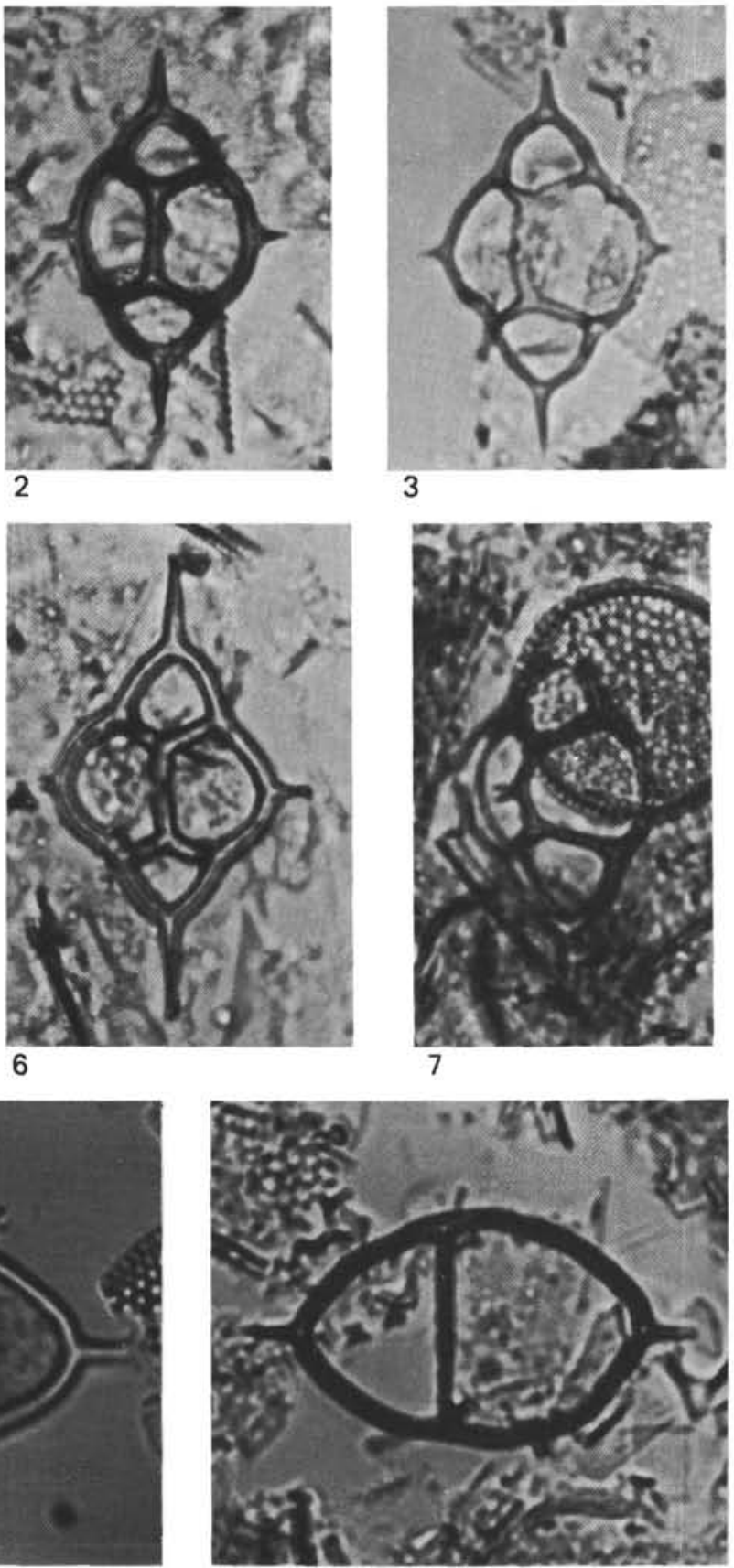

10

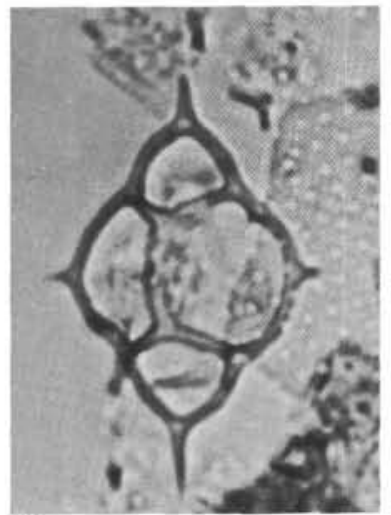

3

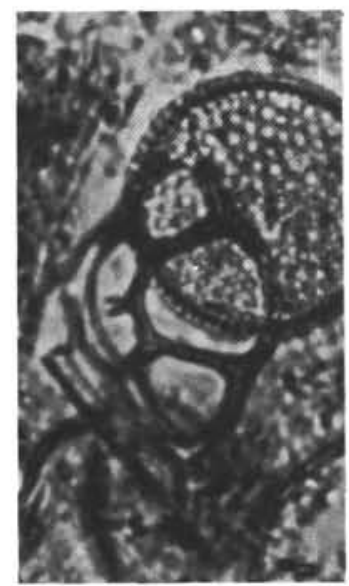

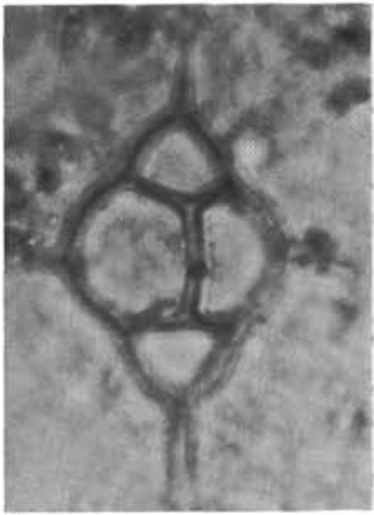

4

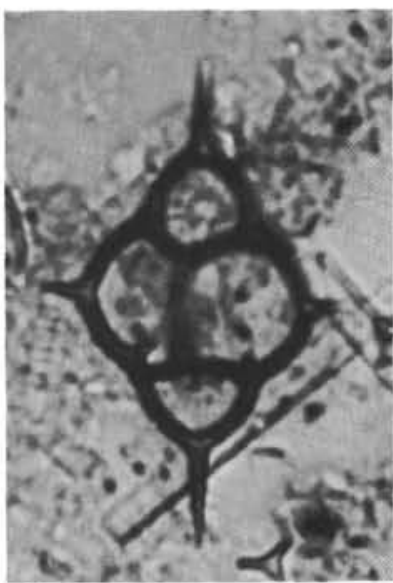

8

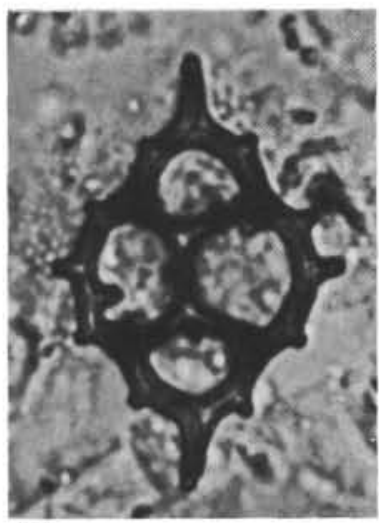

11

Plate 3. Silicoflagellates from DSDP Site 495. (Magnification $800 \times$; scale bar equals $10 \mu \mathrm{m}$.) 1-2. Dictyocha longa Bukry, n. sp. (1) USNM 309691, Sample 495-13-2, 7-9 cm, (2) USNM 309692, Sample 495-11-2, 48-50 cm. 3-8. Dictyocha longa Bukry var. paxilla Bukry, n. var. (3) Holotype, USNM 309693, Sample 495-11-2, 48-50 cm, (4) USNM 309694, Sample 495-11-2, 48-50 cm, (5) USNM 309695, Sample 495-13-2, 7-9 cm, (6) USNM 309696, Sample 495-13-2, 7-9 cm, (7) USNM 309697, tilted, Sample 495-14-2, 20-22 cm, (8) USNM 309698, Sample 495-11-2, 48-50 cm. 9-10. Dictyocha neonautica Bukry var. cocosensis Bukry. All specimens are from Sample 495-14-2, 20-22 cm. 11. Dictyocha ornata africana Bukry, n. subsp. USNM 309699, especially thick specimen from Sample 495-9-3, 50-52 cm. 


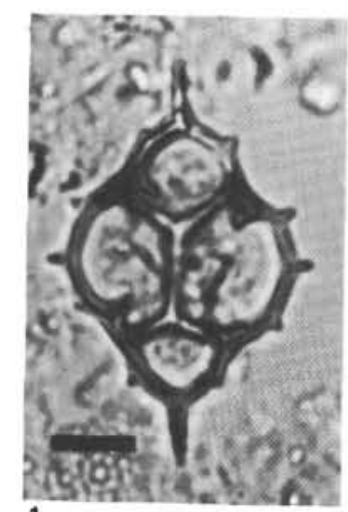

$$
1
$$

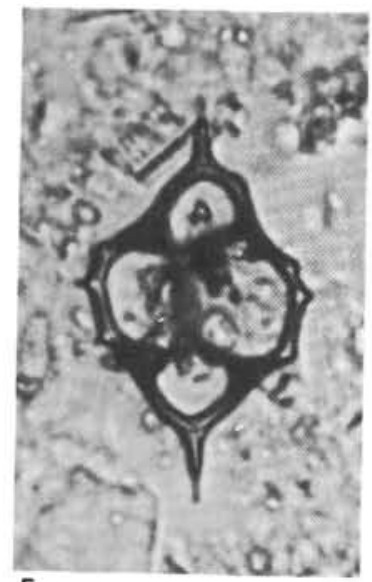

5

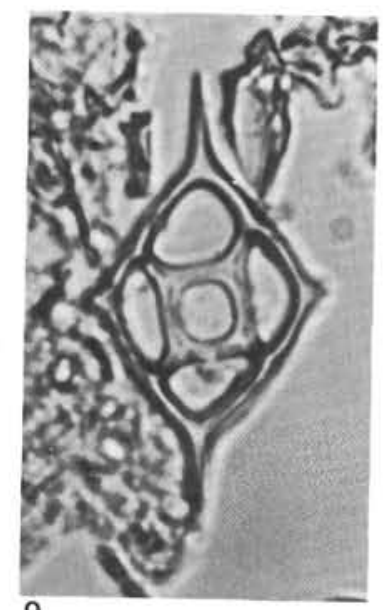

9

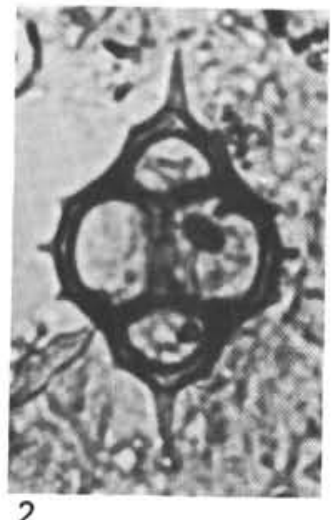

2

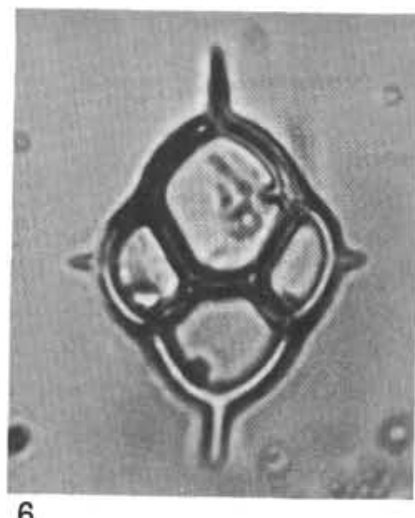

6
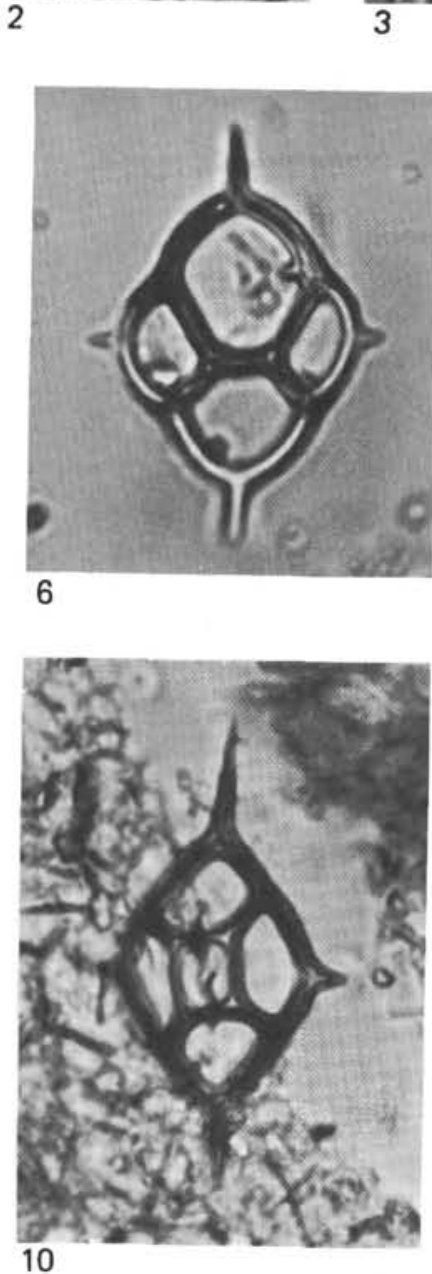
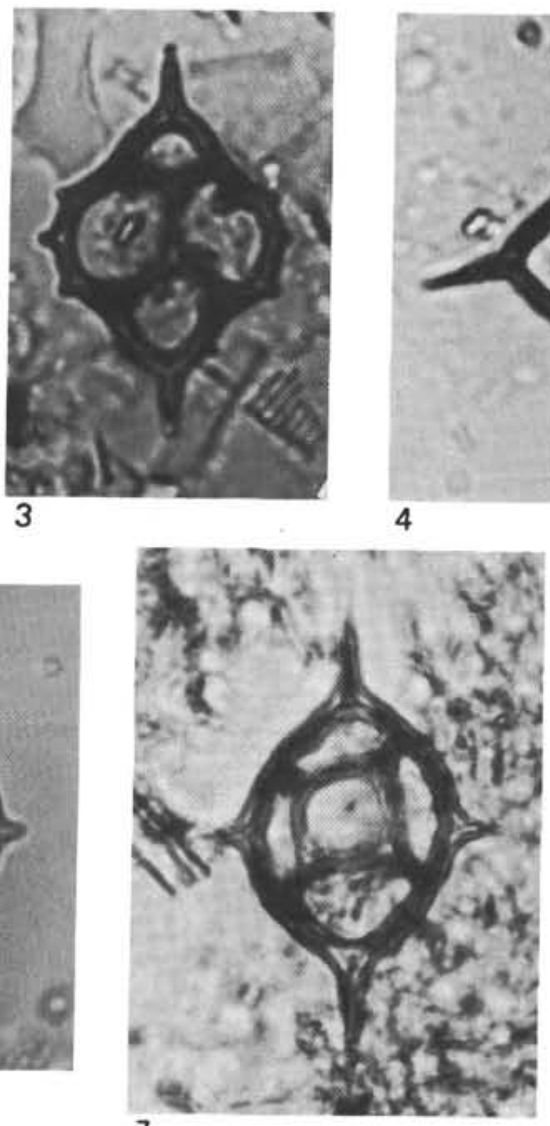

7

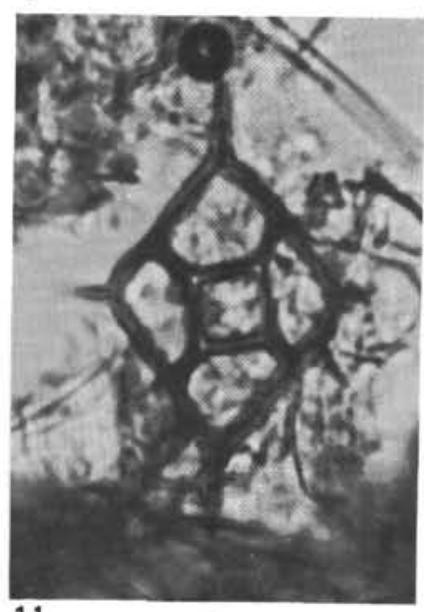

11
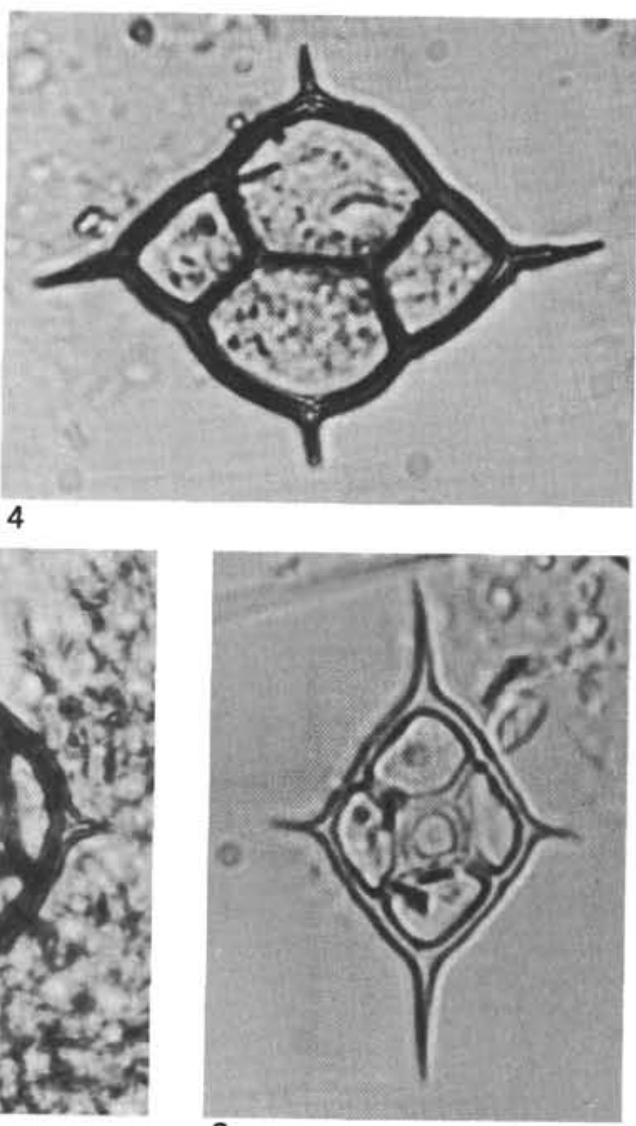

8

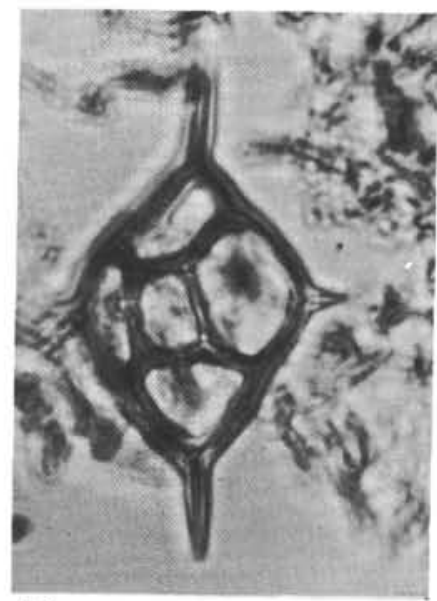

12

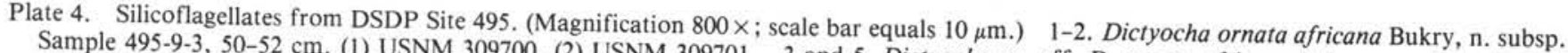
495-9-3, 50-52 cm 4. $\mathrm{cm}$. (1) USNM 309700, (2) USNM 309701. 3 and 5. Dictyocha sp. aff. D. ornata africana Bukry, n. subsp. Sample $100-102 \mathrm{~cm}$. 7. Distephanus crux parvus (Bachmann) Bukry. Sample 495-8-1, 14-16 cm. 6. Dictyocha pulchella Bukry. Sample 495-20-1, subsp. (8) USNM 309703, 495-33-4, 48-50 cm, (11) USNM 309705, Sample 495-31-1, Holotype, USNM 309702, Sample 495-33-4, 48-50 cm, (10) USNM 309704, Sample 


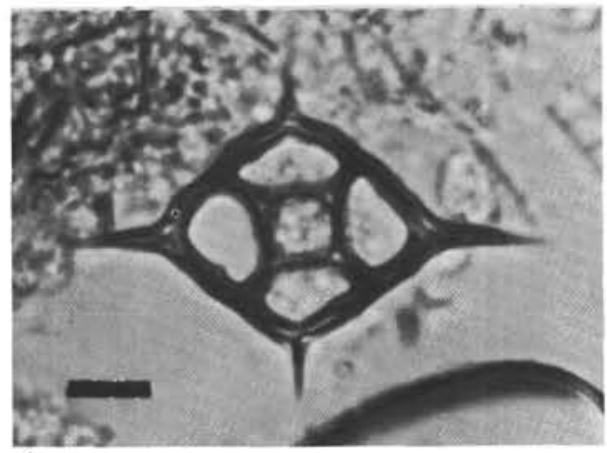

1

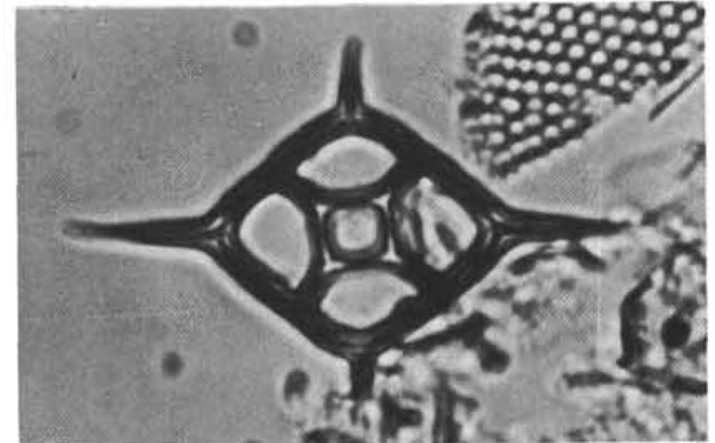

2

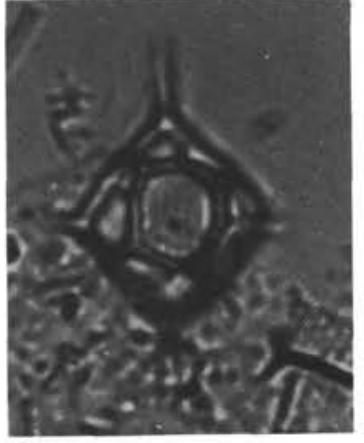

3

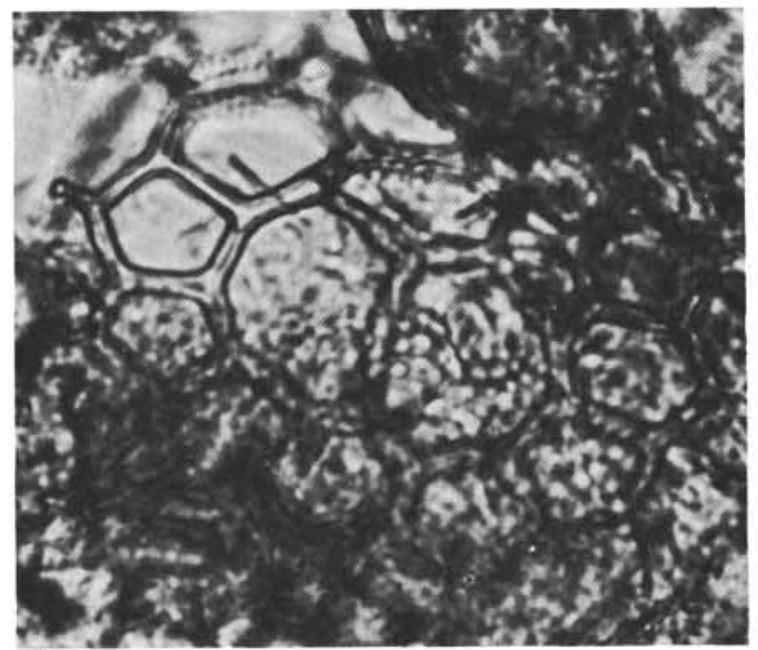

4

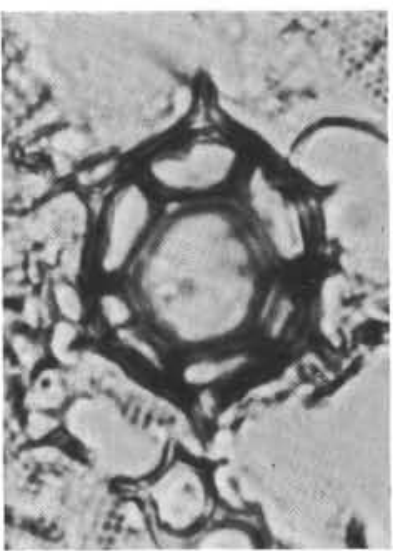

7

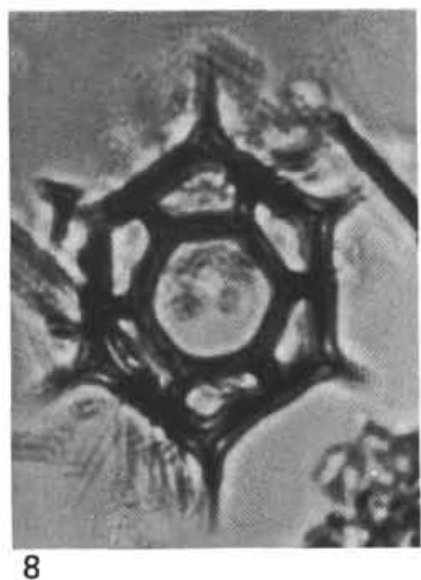

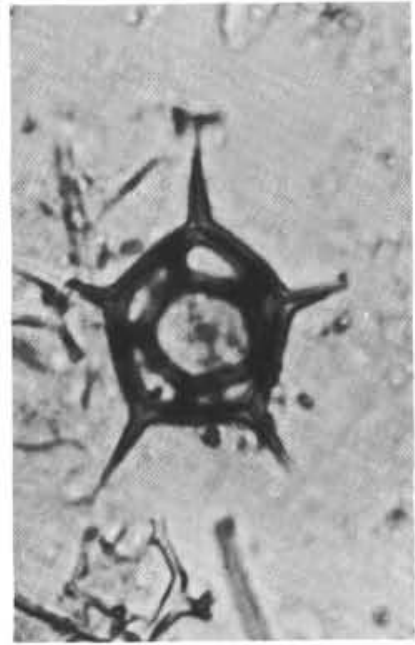

5

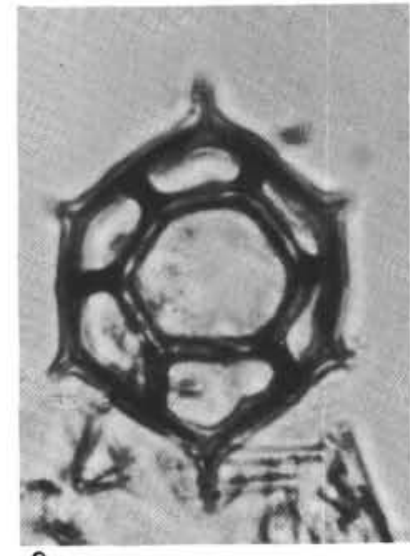

9

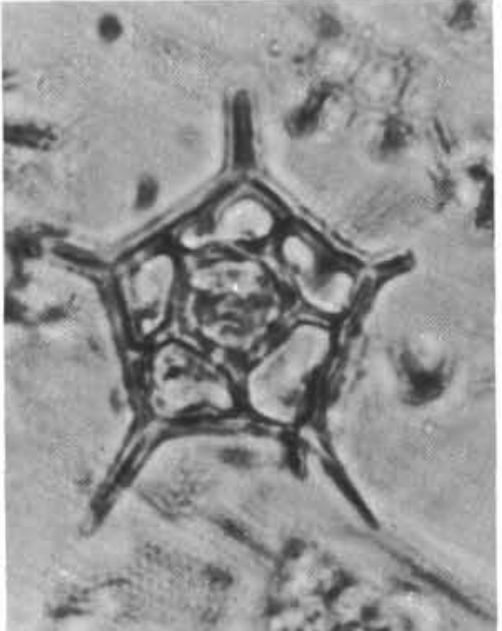

6

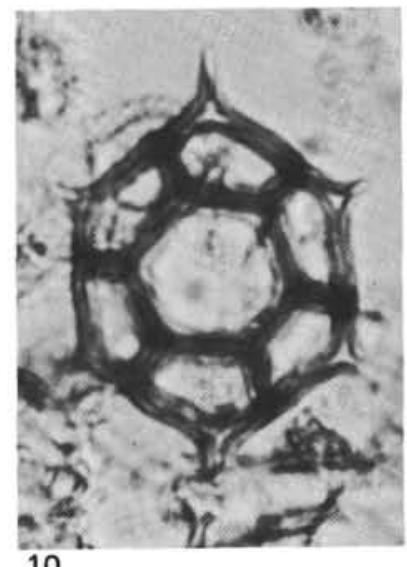

Plate 5. Silicoflagellates from DSDP Site 495. (Magnification $800 \times$; scale bar equals $10 \mu \mathrm{m}$.) 1-2. Distephanus crux scutulatus Bukry, n. subsp. Sample 495-31-1, 48-50 cm. (1) USNM 309707, (2) USNM 309708. 3. Distephanus mesophthalmus (Ehrenberg). Sample 495-14-2, 20-22 $\mathrm{cm}$. 4. Distephanus polyactis (Ehrenberg) var. literatus Bukry, n. var. Holotype, USNM 309709, Sample 495-14-2, 20-22 cm. 5-6. Distephanus quinquangellus Bukry and Foster. (5) Sample 495-8-1, 14-16 cm, (6) Sample 495-17-1, 10-12 cm. 7-10. Distephanus speculum patulus Bukry, n. subsp. (7) Holotype, USNM 309710, Sample 495-32-5, 48-50 cm, (8) USNM 309711, Sample 495-31-1, 48-50 cm, (9) USNM 309712, Sample 495-33-4, 48-50 cm, (10) USNM 309713, Sample 495-33-4, 48-50 cm. 


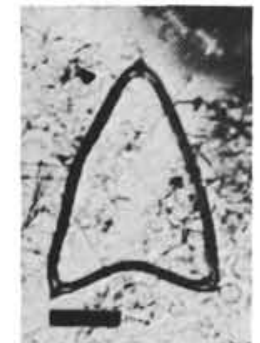

1
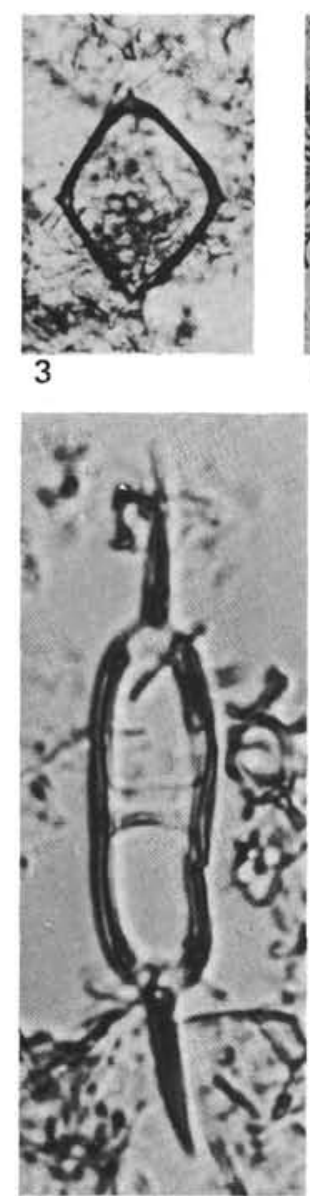

9
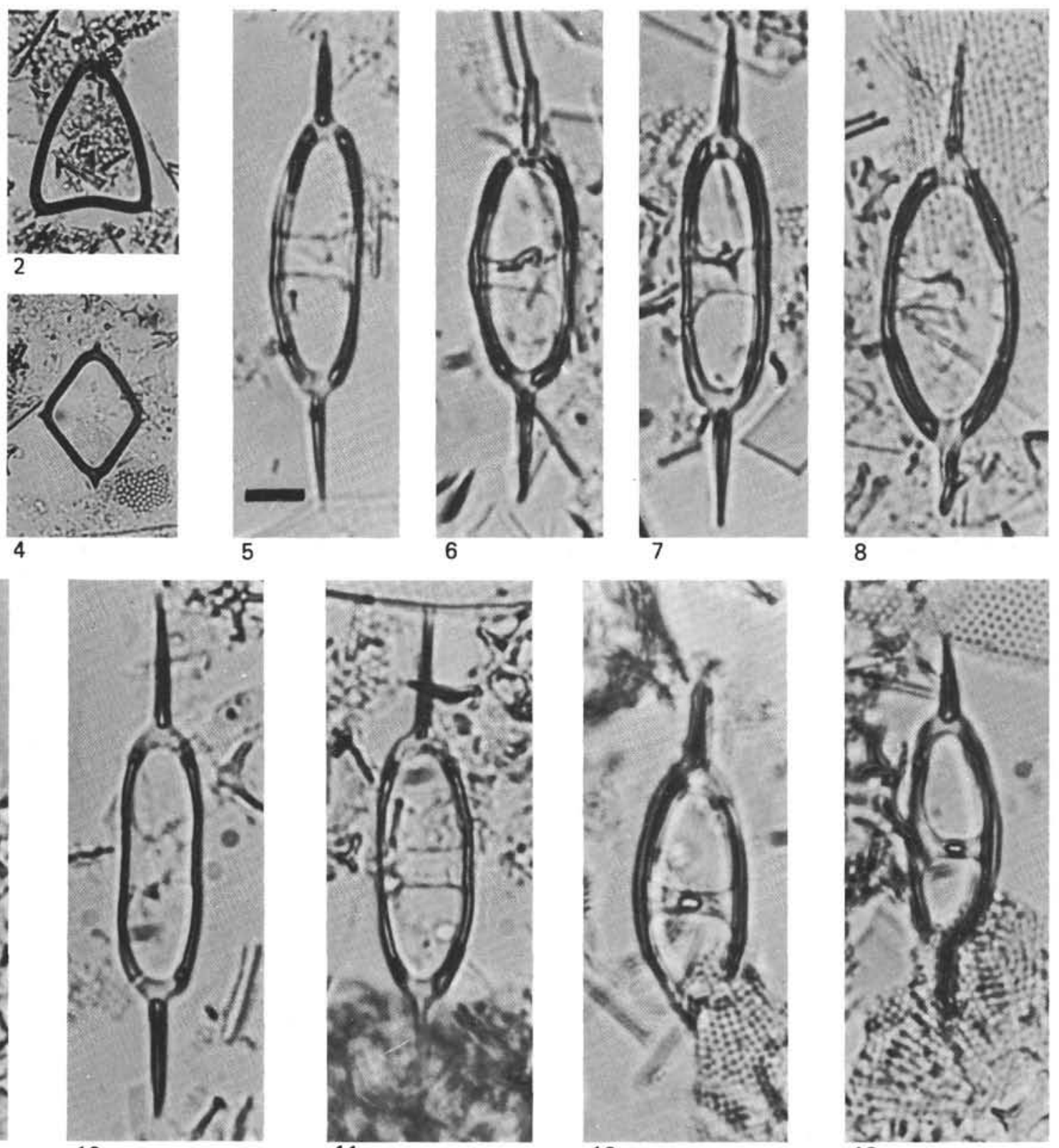

10

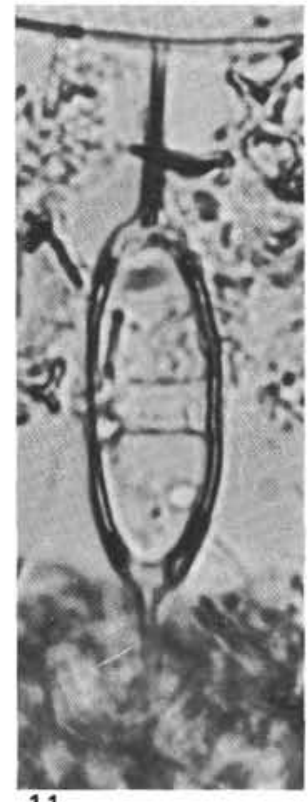

11

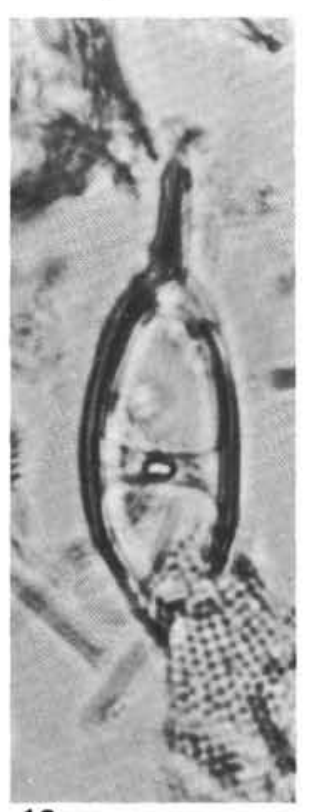

12

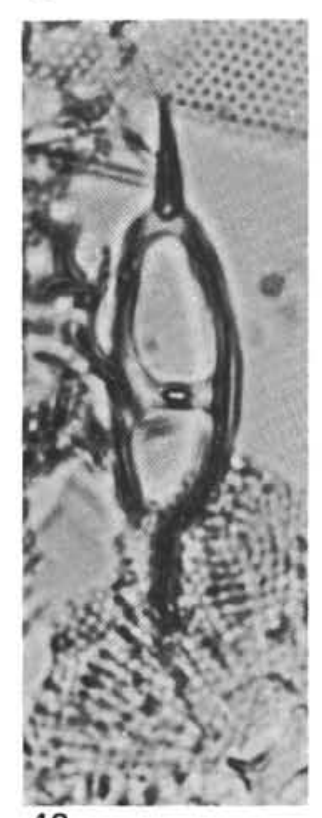

13

Plate 6. Silicoflagellates from DSDP Site 495. (Figs. 1-4, magnification $350 \times$; scale bar equal $20 \mu \mathrm{m}$. Figs. 5-13, magnification $800 \times$; scale bar equals $10 \mu \mathrm{m}$.) 1-2. Mesocena apiculata curvata Bukry. (1) Sample 495-29-1, 50-52 cm, (2) Sample 495-29-5, 50-52 cm. 3-4. Mesocena sp. cf. M. quadrangula Ehrenberg ex Haeckel. (3) Sample 495-33-4, 48-50 cm, (4) Sample 495-32-5, $48-50 \mathrm{~cm}$. 5-13. Naviculopsis contraria Bukry, n. sp. All specimens are from Sample 495-31-5, 48-50 cm. (5) Holotype, USNM 309714, (6) USNM 309715, (7) USNM 309716, (8) USNM 309717, (9) USNM 309718, (10) USNM 309719, (11) USNM 309720, (12) USNM 309721, spired, (13) USNM 309722, spired. 


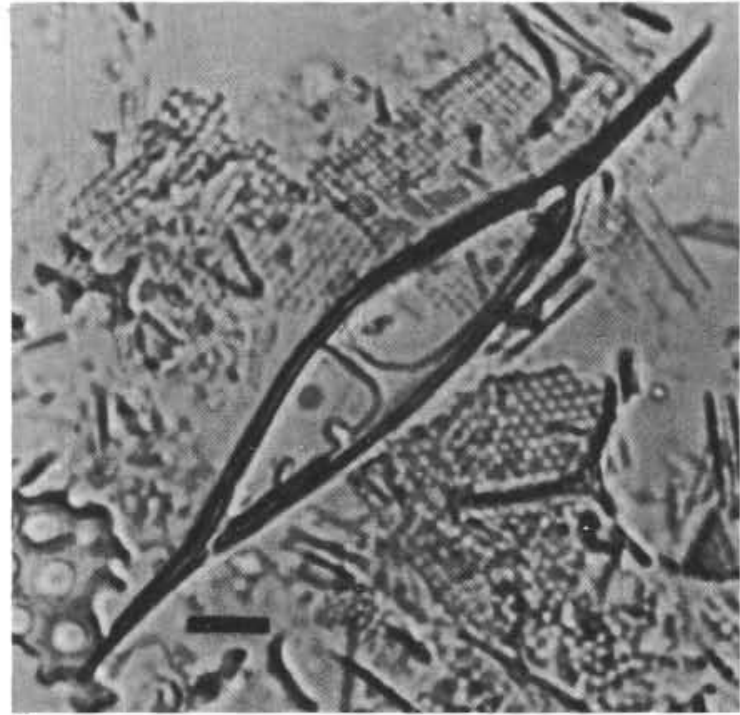

1
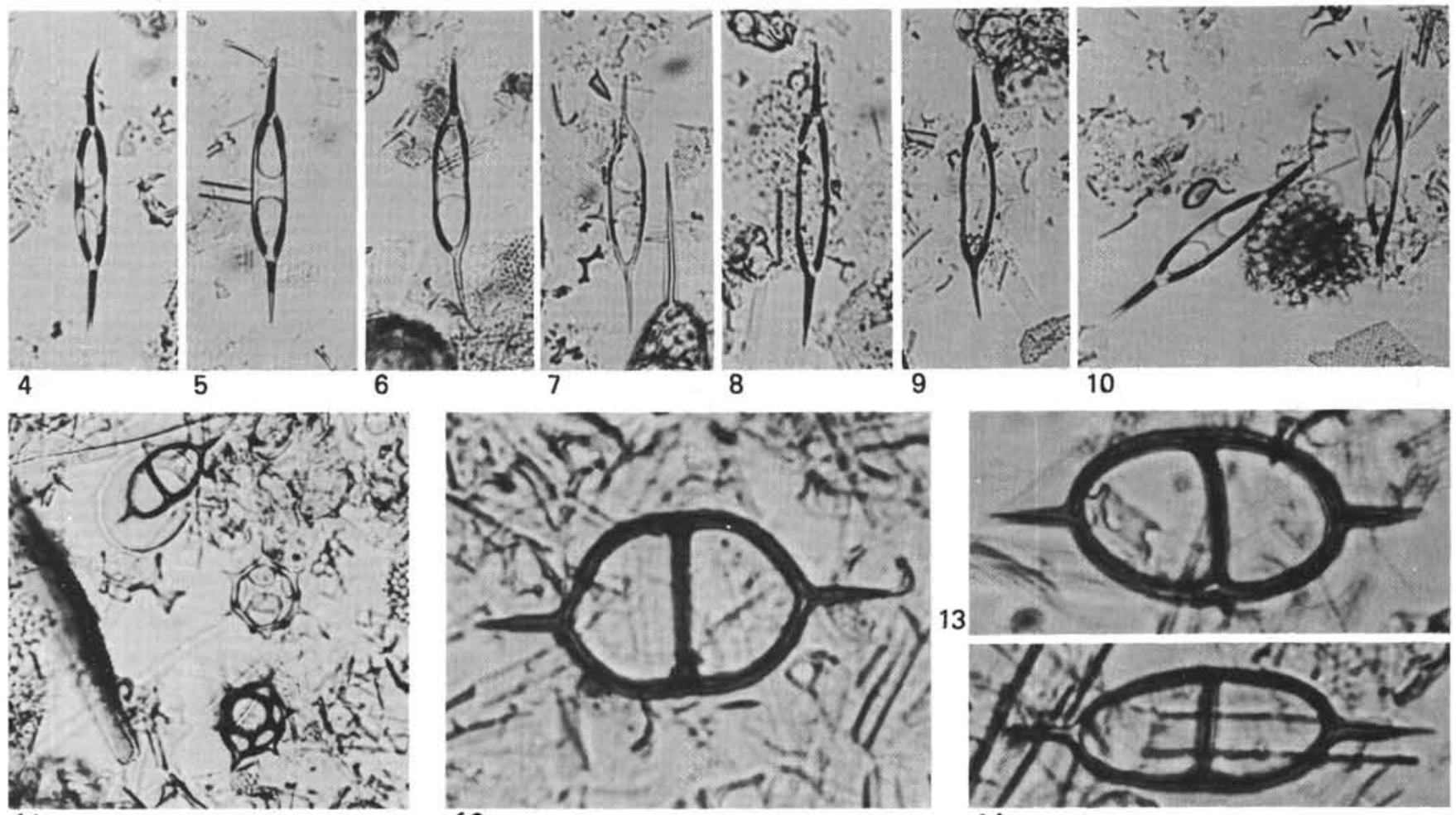

11
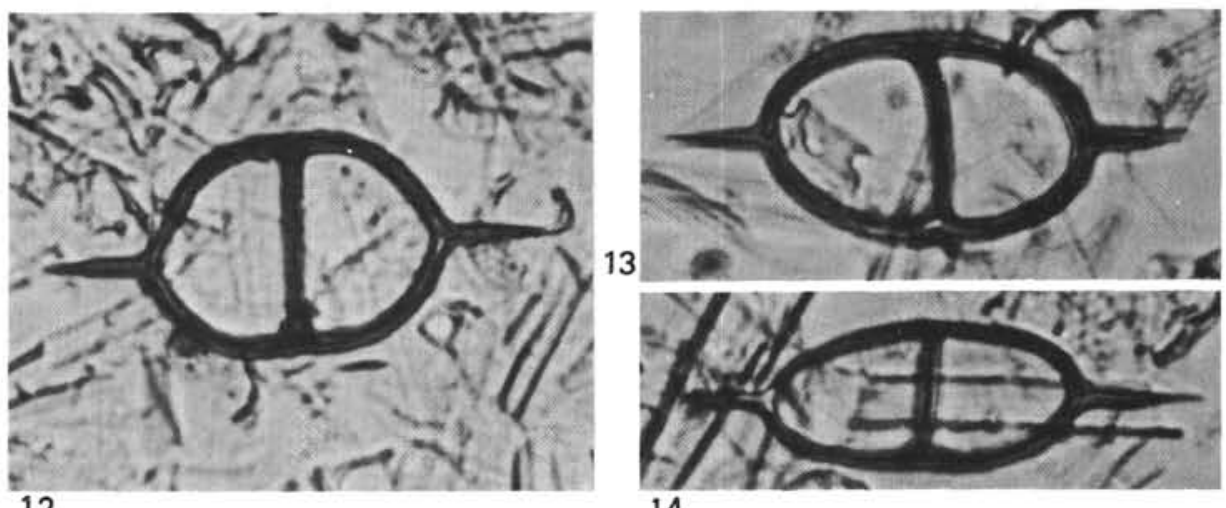

14

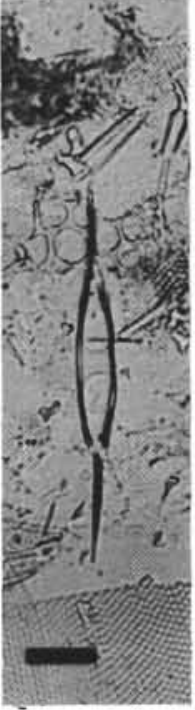

3

Plate 7. Silicoflagellates from DSDP Site 495. (Figs. 1-2, 12-14, magnification $800 \times$; scale bar equals $10 \mu$ m. Figs. 3-11, magnification $350 \times$; scale bar equals $20 \mu \mathrm{m}$.) 1-10. Naviculopsis lacrima Bukry, n. sp. All specimens are from Sample 495-32-2, 48-50 cm. (1) USNM 309724, (2) USNM 309725, (3) Holotype, USNM 309723, (4) USNM 309726, (5) USNM 309727, (6) USNM 309728, (7) USNM 309729, (8) USNM 309730, (9) USNM 309731, (10) USNM 309732 at left, USNM 309733 at right. 11-14. Naviculopsis lata Deflandre. All specimens are from Sample 495-36-4, 45-47 cm. (11) Microscope field of acid-residue strewn slide with other silicoflagellates and diatoms, $N$. lata at top. (12-14) Range from wide to narrow specimens. 

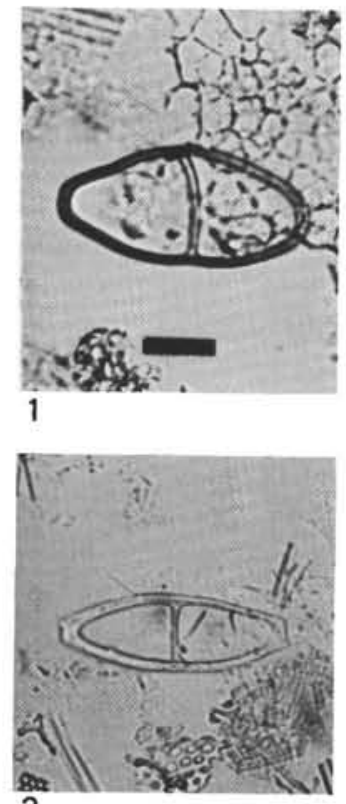

2

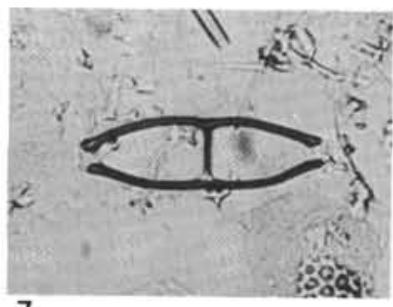

7

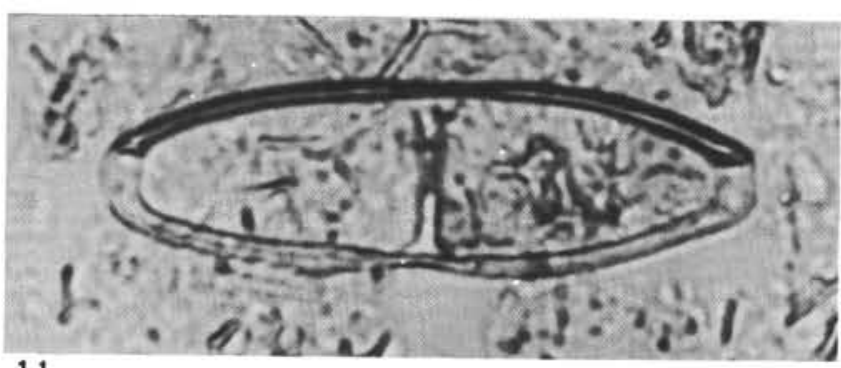

11

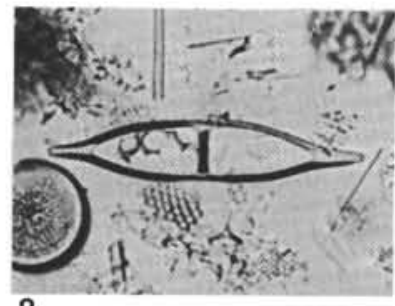

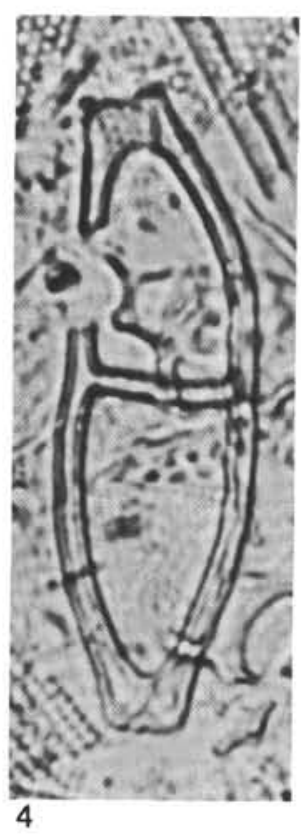
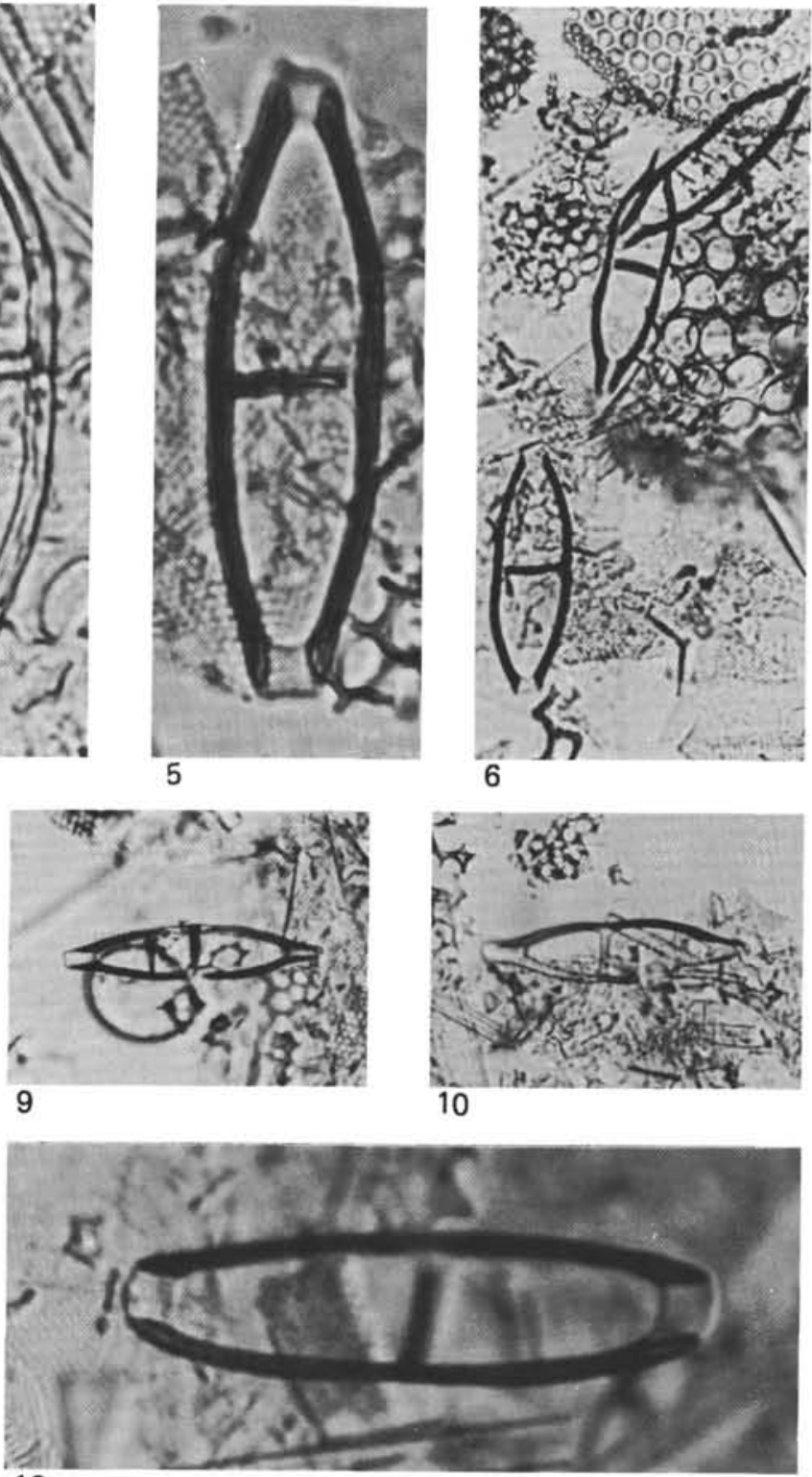

12

Plate 8. Silicoflagellates from DSDP Site 495. (Figs. 1-2, 6-10, magnification $350 \times$; scale bar equals 20 $\mu$ m. Figs. 3-5, 11-12, magnification $800 \times$; scale $10 \mu \mathrm{m}$.) 1. Naviculopsis navicula (Ehrenberg). Sample $495-32-5,48-50 \mathrm{~cm}$. 2-7. Naviculopsis obtusarca Bukry. All specimens are from Sample 495-32-2, 48-50 cm. (2-5, 7) Isolated specimens, (6) strewn slide field showing two specimens of $N$. sp. cf. $N$. obtusarca at upper right. 8-10. Naviculopsis sp. cf. N. obtusarca Bukry. All specimens are from Sample 495-32-2, 48-50 cm. 11-12. Naviculopsis ponticula ponticula (Ehrenberg). (11) Sample 495-31-3, 48-50 cm, (12) Sample 495-31-1, 48-50 cm. 

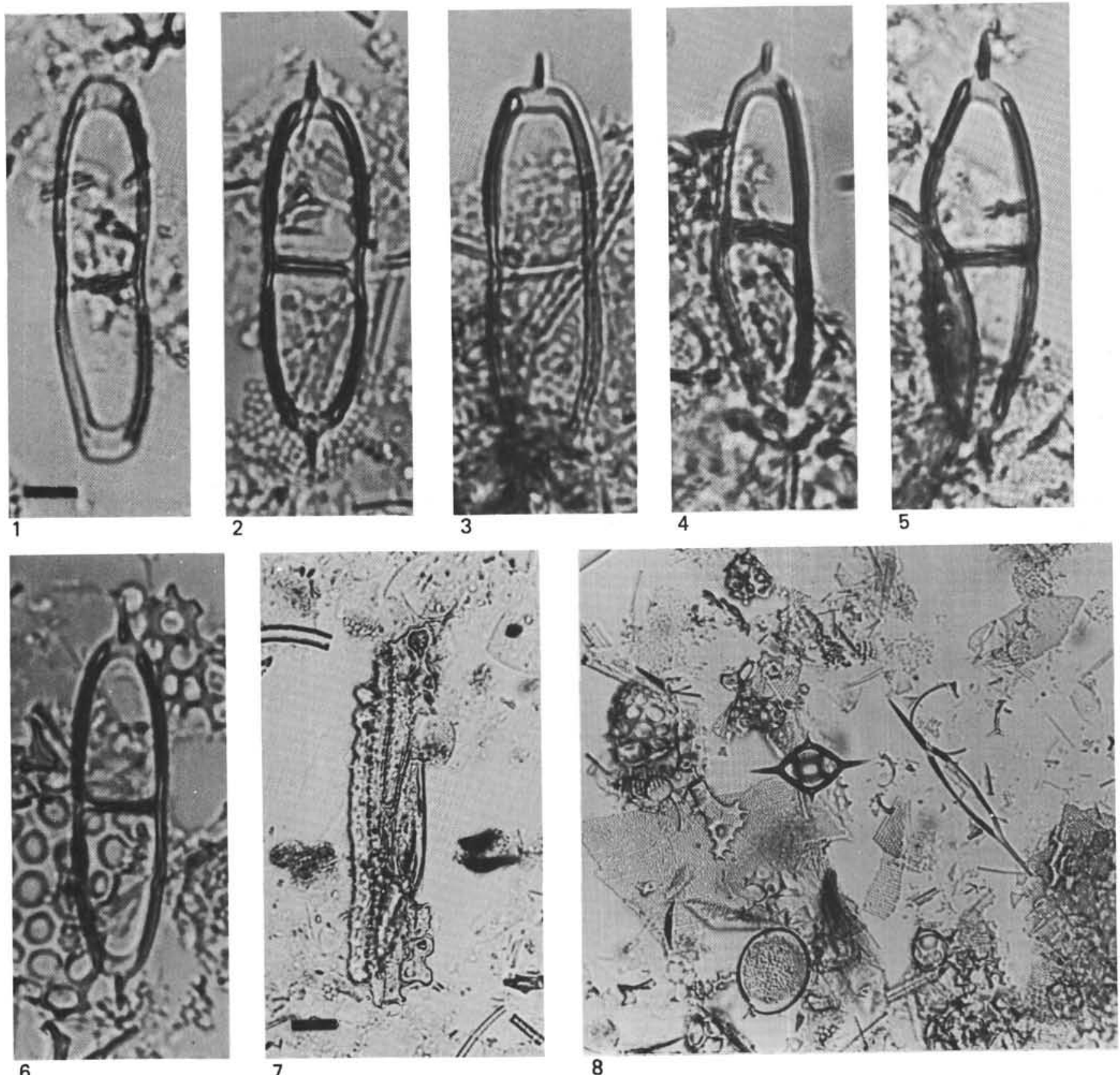

8

Plate 9. Silicoflagellates and opal phytoliths from DSDP Site 495. (Figs. 1-6, magnification $800 \times$; scale bar equals $10 \mu \mathrm{m}$. Figs. 7-8, magnification $350 \times$; scale bar equals $20 \mu \mathrm{m}$.) 1. Naviculopsis ponticula ponticula (Ehrenberg). Sample 495-31-3, 48-50 cm. 2-6. Naviculopsis ponticula spinosa Bukry, n. subsp. All specimens are from Sample 495-31-1, 48-50 cm. (2) Holotype, USNM 309734, (3) USNM 309735, (4) USNM 309736, (5) USNM 309737, (6) USNM 309738, 7. Grass sliver with two panicoid opal phytoliths. Sample 495-8-1, 14-16 cm. 8. Strewn slide field with specimens of Distephanus crux scutulatus Bukry, n. subsp., USNM 309739, and Naviculopsis lacrima Bukry, n. sp., USNM 309725, Sample 495-32-2, 48-50 cm. 